\title{
Gas-phase radical chemistry in the troposphere
}

\author{
Paul S. Monks \\ Received 22nd November 2004 \\ First published as an Advance Article on the web 28th February 2005 \\ DOI: $10.1039 / \mathrm{b307982c}$
}

\begin{abstract}
Atmospheric free radicals are low concentration, relatively fast reacting species whose influence is felt throughout the atmosphere. Reactive radicals have a key role in maintaining a balanced atmospheric composition through their central function in controlling the oxidative capacity of the atmosphere. In this tutorial review, the chemistry of three main groups of atmospheric radicals $\mathrm{HO}_{x}, \mathrm{NO}_{x}$ and $\mathrm{XO}_{x}(\mathrm{X}=\mathrm{Cl}, \mathrm{Br}, \mathrm{I})$ are examined in terms of their sources, interconversions and sinks. Key examples of the chemistry are given for each group of radicals in their atmospheric context.
\end{abstract}

\section{Introduction}

The thin gaseous envelope that surrounds our planet is integral to the maintenance of life on earth. The composition of the atmosphere is predominately determined by biological processes acting in concert with physical and chemical change. Though the concentrations of the major atmospheric constituents oxygen and nitrogen remain the same, the concentration of trace species which are key to many atmospheric processes are changing. It is becoming apparent that man's activities are beginning to change the composition of the atmosphere over a range of scales, leading to, for example increased acid deposition, local and regional ozone episodes, stratospheric ozone loss and potentially climate change.

The troposphere is the lowest region of the atmosphere extending from the Earth's surface to the tropopause at 10$18 \mathrm{~km}$. About $90 \%$ of the total atmospheric mass resides in the

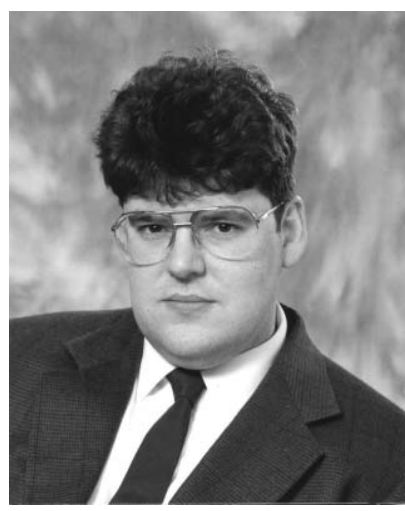

Paul S. Monks
Paul Monks was born in St. Helens in 1968. He received his B.Sc. degree from the University of Warwick and his D.Phil. from the University of Oxford in 1991 with Richard Wayne. In 1992 he took up an NAS/NRC fellowship in Astrochemistry at NASA/Goddard with Lou Stief before returning in 1994 to the UK to work a postdoctoral position with Stuart Penkett at UEA. In 1996 he was appointed to a lectureship in Earth Observation Science in the Department of Chemistry at the University of Leicester and promoted to the current position of a Reader in Atmospheric Chemistry in 2003. Primary research interests are the scientific questions underlying: the role of photochemistry in the control of atmospheric composition; chemistry and transport, particularly the impact of long-range transport on chemical composition; the feedback between climate and atmospheric chemistry; organic complexity and the control of regional pollution and the measurement of the troposphere from space. troposphere and the greater part of the trace gas burden is found there. The troposphere is well mixed and its bulk composition is $78 \% \mathrm{~N}_{2}, 21 \% \mathrm{O}_{2}, 1 \% \mathrm{Ar}$ and $0.036 \% \mathrm{CO}_{2}$ with varying amounts of water vapour depending on temperature and altitude. The majority of the trace species found in the atmosphere are emitted into the troposphere from the surface and are subject to a complex series of chemical and physical transformations.

In general, tropospheric chemistry is analogous to a low temperature combustion system, the overall reaction given by

$$
\mathrm{CH}_{4}+\mathrm{O}_{2} \rightarrow \mathrm{CO}_{2}+2 \mathrm{H}_{2}
$$

Unlike combustion, this is not a thermally initiated process but a process initiated and propagated by photochemistry. Atmospheric photochemistry produces a variety of radicals that exert a substantial influence on the ultimate composition of the atmosphere. In the main, radical species are produced by the interaction of sunlight with photolabile molecules to produce either highly reactive atoms and/or radicals. The photodissociation of trace species and the subsequent reaction of the photoproducts with other molecules is the prime initiator and propagator come driver for the bulk of tropospheric chemistry. The atmospheric abundances of free radical species are very small, typically less than one hundred parts per trillion of air. These low abundances are a consequence of the very reactivity of the radical species. It is free radicals that transform most species in the atmosphere.

The chemistry and ultimate fate of tropospheric radicals impinges on a wide-range of contemporary environmental topics, from the control of greenhouse gas lifetimes (climate change), the formation of atmospheric acids (acid rain) and the production of ground-level ozone and secondary organic aerosols (photochemical smog, regional air quality and global air pollution).

This tutorial review looks at the role of gas-phase radical species in the control of atmospheric composition. The review has been built from the current state of knowledge from a measurement viewpoint of radical chemistry and focuses on the current understanding of the oxidative chemistry of the (lower) atmosphere. The chemistry of three main groups of atmospheric radicals $\mathrm{HO}_{x}$ (and $\mathrm{RO}_{x}$, where $\mathrm{R}$ is an organic 
substituent), $\mathrm{NO}_{x}$ and $\mathrm{XO}_{x}(\mathrm{X}=\mathrm{Cl}, \mathrm{Br}, \mathrm{I})$ are examined in terms of their sources, interconversions and sinks. As atmospheric science is observationally driven, key examples are given for each group of radicals of the measurement context for the free radical chemistry.

\section{Atmospheric radicals}

\section{The hydroxyl radical $\mathrm{OH}$ and the peroxy radicals $\mathrm{HO}_{2}$ and $\mathrm{RO}_{2}$}

Atmospheric photochemistry produces a variety of radicals that exert a substantial influence on the ultimate composition of the atmosphere. The most important of these in terms of its reactivity is the hydroxyl radical, $\mathrm{OH}$. The formation of $\mathrm{OH}$ is the initiator of radical-chain oxidation. Photolysis of ozone by ultraviolet light in the presence of water vapour is the main source of hydroxyl radicals in the troposphere viz.

$$
\begin{gathered}
\mathrm{O}_{3}+h v(\lambda<320 \mathrm{~nm}) \rightarrow \mathrm{O}\left({ }^{1} \mathrm{D}\right)+\mathrm{O}_{2}\left({ }^{1} \Delta_{\mathrm{g}}\right) \\
\mathrm{O}\left({ }^{1} \mathrm{D}\right)+\mathrm{H}_{2} \mathrm{O} \rightarrow \mathrm{OH}+\mathrm{OH}
\end{gathered}
$$

The fate of the bulk of the $\mathrm{O}\left({ }^{1} \mathrm{D}\right)$ atoms produced via reaction (2) is collisional quenching back to ground state oxygen atoms viz

$$
\begin{aligned}
& \mathrm{O}\left({ }^{1} \mathrm{D}\right)+\mathrm{N}_{2} \rightarrow \mathrm{O}\left({ }^{3} \mathrm{P}\right)+\mathrm{N}_{2} \\
& \mathrm{O}\left({ }^{1} \mathrm{D}\right)+\mathrm{O}_{2} \rightarrow \mathrm{O}\left({ }^{3} \mathrm{P}\right)+\mathrm{O}_{2}
\end{aligned}
$$

The fraction of $\mathrm{O}\left({ }^{1} \mathrm{D}\right)$ atoms that form $\mathrm{OH}$ is dependent on the concentration of $\mathrm{H}_{2} \mathrm{O}$. Typically in the marine boundary layer, the lowest layer of the atmosphere over the oceans, about $10 \%$ of the $\mathrm{O}\left({ }^{1} \mathrm{D}\right)$ generates $\mathrm{OH}$. Reactions $(2+3)$ are the primary source of $\mathrm{OH}$ in the troposphere, but there are a number of other reactions (see for example reaction 14) and photolysis routes capable of forming $\mathrm{OH}$ directly or indirectly. As these compounds are often products of $\mathrm{OH}$ radical initiated oxidation they are often termed secondary sources of $\mathrm{OH}$ and include the photolysis of $\mathrm{HONO}, \mathrm{HCHO}, \mathrm{H}_{2} \mathrm{O}_{2}$, acetone and the reaction of $\mathrm{O}\left({ }^{1} \mathrm{D}\right)$ with methane (see Fig. 1). Table 1 illustrates the average contribution of various radical formation routes with altitude in the (U.S.) standard atmosphere.

Two important and interrelated features of $\mathrm{OH}$ chemistry make it critical to the chemistry of the troposphere. The first is its inherent reactivity; the second is its relatively high concentration given its high reactivity.

The hydroxyl radical is ubiquitous throughout the troposphere owing to the widespread abundance of ozone and water

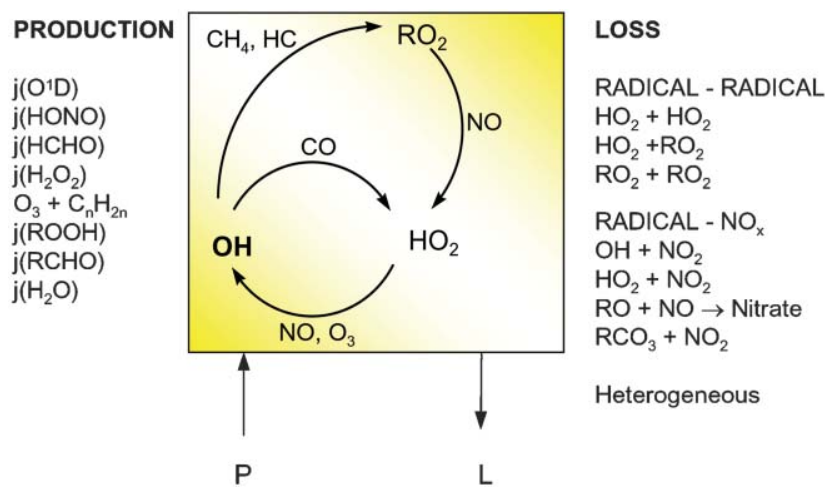

Fig. 1 The sources, interconversions and sinks for $\mathrm{HO}_{x}\left(\right.$ and $\left.\mathrm{RO}_{x}\right)$ in the troposphere.

vapour. First estimates of $\mathrm{OH}$ concentrations ${ }^{1,2}$ have proven to be surprisingly accurate, predicting the concentration to be of the order of $2 \times 10^{6}$ molecules $\mathrm{cm}^{-3}$. A typical diurnal profile for $\mathrm{OH}$ and the measured photochemical rate of reaction (2) (a proxy for $\mathrm{OH}$ production rate) is shown in Fig. 2 for clean air conditions. $\mathrm{OH}$ measurements have been made under a wide range of tropospheric conditions from the urban atmosphere to the background marine atmosphere and from the surface to the upper troposphere. $^{3}$

Hydroxyl radical chemistry cannot be treated in isolation as it is part of a closely coupled system involving $\mathrm{HO}_{x}(\mathrm{OH}$ and $\left.\mathrm{HO}_{2}\right), \mathrm{NO}_{x}\left(\mathrm{NO}\right.$ and $\mathrm{NO}_{2}$ ) and ozone. In relatively unpolluted regimes (low $\mathrm{NO}_{x}$ ) the main fate for the hydroxyl radical is reaction with either carbon monoxide or methane to produce peroxy radicals such as $\mathrm{HO}_{2}$ and $\mathrm{CH}_{3} \mathrm{O}_{2}$, viz

$$
\mathrm{OH}+\mathrm{CO} \rightarrow \mathrm{H}+\mathrm{CO}_{2}
$$

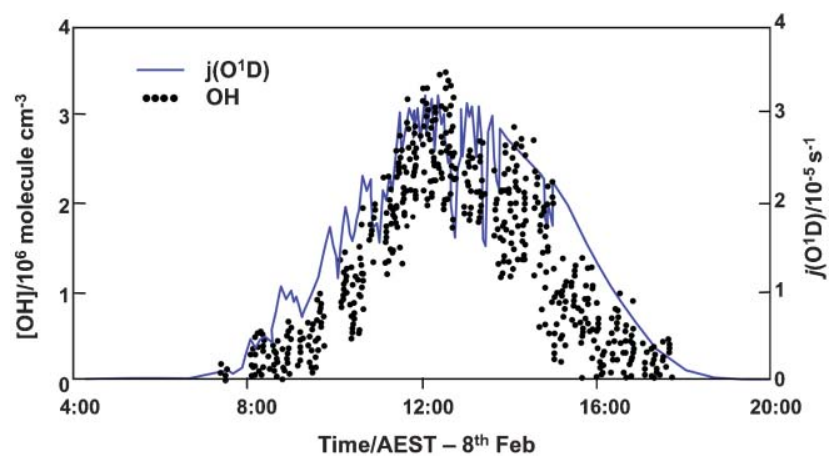

\begin{tabular}{|c|c|c|c|c|c|}
\hline Altitude & $j\left(\mathrm{O}\left({ }^{1} \mathrm{D}\right)\right)+\mathrm{H}_{2} \mathrm{O}$ & $j\left(\mathrm{O}\left({ }^{1} \mathrm{D}\right)\right)+\mathrm{CH}_{4}$ & $j$ (Acetone) & $j\left(\mathrm{H}_{2} \mathrm{O}_{2}\right)$ & $j(\mathrm{HCHO})$ \\
\hline Ground & 0.68 & 0.0 & Neg. & 0.15 & 0.17 \\
\hline Mid-troposphere & 0.52 & Neg. & 0.03 & 0.20 & 0.25 \\
\hline Upper-troposphere & 0.35 & 0.02 & 0.1 & 0.25 & 0.28 \\
\hline Lower stratosphere & 0.40 & 0.1 & 0.25 & 0.1 & 0.15 \\
\hline
\end{tabular}

Fig. 2 Typical diurnal variation of $[\mathrm{OH}]$ and $j\left(\mathrm{O}^{1} \mathrm{D}\right)$ (reaction 2) in the clean marine atmosphere (the time is in Australian Eastern Standard Time). ${ }^{62}$

Table 1 Calculated fractional contribution of various photolysis rates to radical production $(\mathrm{OH})$ with altitude for clean conditions 
and

$$
\mathrm{H}+\mathrm{O}_{2}+\mathrm{M} \rightarrow \mathrm{HO}_{2}+\mathrm{M}
$$

$$
\begin{gathered}
\mathrm{OH}+\mathrm{CH}_{4} \rightarrow \mathrm{CH}_{3}+\mathrm{H}_{2} \mathrm{O} \\
\mathrm{CH}_{3}+\mathrm{O}_{2}+\mathrm{M} \rightarrow \mathrm{CH}_{3} \mathrm{O}_{2}+\mathrm{M}
\end{gathered}
$$

where $\mathrm{M}$ is a third body that acts only to collisionally stabilize the association complex. Fig. 3 shows a typical diurnal cycle of peroxy radicals measured in the marine environment at Mace Head in Ireland. ${ }^{4}$ Peroxy radical concentrations, though relatively small, are substantially larger ( $c$ a. 50-100 times) than the concomitant $\mathrm{OH}$ concentration (for comparison see Fig. 2). $\mathrm{HO}_{2}$, the major peroxy radical has a lifetime of about a minute in clean air and much less than a minute in dirty air.

In low- $\mathrm{NO}_{x}$ conditions, $\mathrm{HO}_{2}$ can react with ozone leading to further destruction of ozone in a chain sequence involving formation of hydroxyl radicals

$$
\begin{gathered}
\mathrm{HO}_{2}+\mathrm{O}_{3} \rightarrow \mathrm{OH}+2 \mathrm{O}_{2} \\
\mathrm{OH}+\mathrm{O}_{3} \rightarrow \mathrm{HO}_{2}+\mathrm{O}_{2}
\end{gathered}
$$

Alternatively, it can recombine to form hydrogen peroxide $\left(\mathrm{H}_{2} \mathrm{O}_{2}\right)$

$$
\mathrm{HO}_{2}+\mathrm{HO}_{2} \rightarrow \mathrm{H}_{2} \mathrm{O}_{2}+\mathrm{O}_{2}
$$

or react with organic peroxy radicals such as $\mathrm{CH}_{3} \mathrm{O}_{2}$ to form organic hydroperoxides,

$$
\mathrm{CH}_{3} \mathrm{O}_{2}+\mathrm{HO}_{2} \rightarrow \mathrm{CH}_{3} \mathrm{O}_{2} \mathrm{H}+\mathrm{O}_{2}
$$

The formation of peroxides is effectively a chain termination reaction, as under most conditions these peroxides can act as effective sinks for $\mathrm{HO}_{x}$ (See Fig. 1). In more polluted conditions (high- $\mathrm{NO}_{x}$ ), the reactions to form peroxides (12 and 13) compete with the peroxy radical catalysed oxidation of $\mathrm{NO}$ to $\mathrm{NO}_{2}$

$$
\mathrm{HO}_{2}+\mathrm{NO} \rightarrow \mathrm{OH}+\mathrm{NO}_{2}
$$

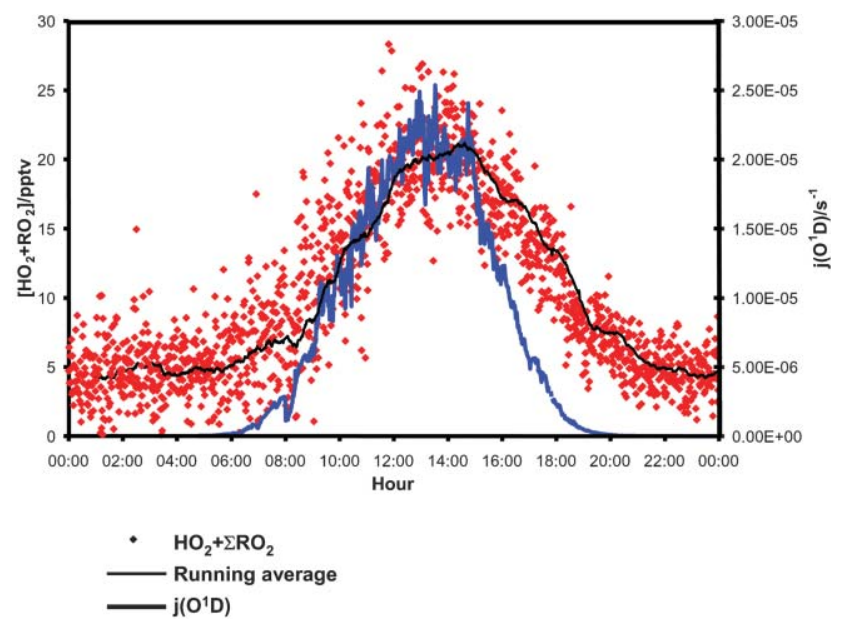

Fig. 3 Typical diurnal variation of $\left[\mathrm{HO}_{2}+\Sigma \mathrm{RO}_{2}\right]$ (in parts per trillion by volume, pptv) and $j\left(\mathrm{O}^{1} \mathrm{D}\right)($ reaction 2$)$ in the clean marine atmosphere. $^{4}$ leading to the production of ozone from the subsequent photolysis of nitrogen dioxide and reaction of the $\mathrm{O}\left({ }^{3} \mathrm{P}\right)$ photoproduct, i.e.

$$
\begin{gathered}
\mathrm{NO}_{2}+h v(\lambda<420 \mathrm{~nm}) \rightarrow \mathrm{NO}+\mathrm{O}\left({ }^{3} \mathrm{P}\right) \\
\mathrm{O}\left({ }^{3} \mathrm{P}\right)+\mathrm{O}_{2}+\mathrm{M} \rightarrow \mathrm{O}_{3}+\mathrm{M}
\end{gathered}
$$

Hydroxyl radicals produced in reaction (14) can go on to form more peroxy radicals (e.g. via reactions 6 and 8 ). Similarly to $\mathrm{HO}_{2}, \mathrm{CH}_{3} \mathrm{O}_{2}$ can also oxidise $\mathrm{NO}$ to $\mathrm{NO}_{2}$

$$
\mathrm{CH}_{3} \mathrm{O}_{2}+\mathrm{NO} \rightarrow \mathrm{CH}_{3} \mathrm{O}+\mathrm{NO}_{2}
$$

The resulting methoxy radical reacts rapidly with $\mathrm{O}_{2}$ to form formaldehyde and $\mathrm{HO}_{2}$

$$
\mathrm{CH}_{3} \mathrm{O}+\mathrm{O}_{2} \rightarrow \mathrm{HCHO}+\mathrm{HO}_{2}
$$

The oxidation of methane is summarised schematically in Fig. 4. The oxidation of methane is illustrative of the major role of the hydroxyl radical in that the atmospheric concentration of $\mathrm{CH}_{4}$ is in the main controlled by reaction with $\mathrm{OH}$ (see Table 2).

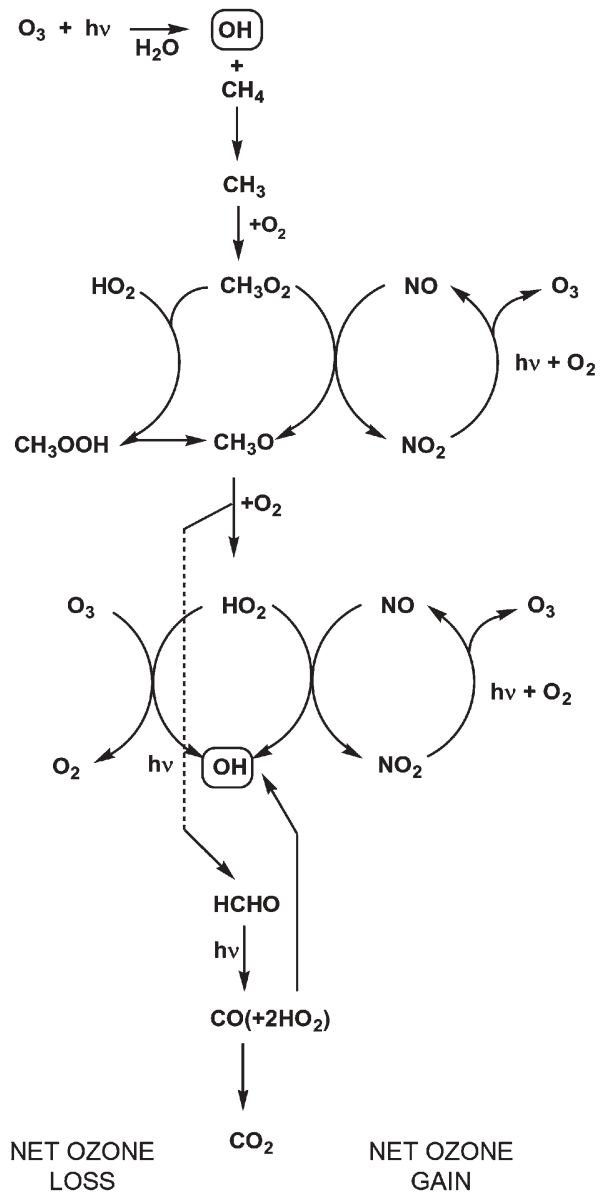

Fig. 4 Simplified mechanism for the photochemical oxidation of $\mathrm{CH}_{4}$ in the troposphere (after ref. 63). 
Table 2 Global turnover of tropospheric gases and fraction removed by reaction with $\mathrm{OH}^{11}$

\begin{tabular}{|c|c|c|}
\hline Trace Gas & $\begin{array}{l}\text { Global emission } \\
\text { rate } / \mathrm{Tg} \mathrm{yr}^{-1}\end{array}$ & $\begin{array}{l}\text { Removal by } \\
\mathrm{OH}^{a}(\%)\end{array}$ \\
\hline $\mathrm{CO}$ & 2800 & 85 \\
\hline $\mathrm{CH}_{4}$ & 530 & 90 \\
\hline $\mathrm{C}_{2} \mathrm{H}_{6}$ & 20 & 90 \\
\hline Isoprene & 570 & 90 \\
\hline Terpenes & 140 & 50 \\
\hline $\mathrm{NO}_{2}$ & 150 & 50 \\
\hline $\mathrm{SO}_{2}$ & 300 & 30 \\
\hline$\left(\mathrm{CH}_{3}\right)_{2} \mathrm{~S}$ & 30 & 90 \\
\hline $\mathrm{CFCl}_{3}$ & 0.3 & 0 \\
\hline
\end{tabular}

The $\mathrm{OH}$ radical may have another fate, dependent on the concentration of $\mathrm{NO}_{2}$, in that it can react with $\mathrm{NO}_{2}$ to form nitric acid

$$
\mathrm{OH}+\mathrm{NO}_{2}+\mathrm{M} \rightarrow \mathrm{HNO}_{3}+\mathrm{M}
$$

The formation of $\mathrm{HNO}_{3}$ represents an effective loss mechanism for both $\mathrm{HO}_{x}$ and $\mathrm{NO}_{x}$. The hydroxyl radical lifetime, under the majority of conditions, is less than a second, the upper limit of its concentration being determined by reaction (8).

One of the roles of atmospheric radical chemistry, as driven by $\mathrm{OH}$, is to "cleanse" the troposphere of a wide-range of the organic compounds. The $\mathrm{OH}$ radical is known to react with most trace gases and in many instances it is the first and rate determining step. Thus, $\mathrm{OH}$ controls the removal and, therefore, the tropospheric concentrations of many trace gases. Table 2 illustrates the global turnover of a range of trace gases including hydrocarbons and illustrates, for a number of trace gases, the primary role played by $\mathrm{OH}$ in their removal. There has been much debate as to whether the oxidative capacity of the troposphere has changed with industrialisation (see Fig. 5). ${ }^{5}$ Global "OH", a sometime used measure of oxidative capacity, has proven to be a difficult concept and has been developed to represent the diurnal mean ability of the atmosphere to oxidise trace compounds. The coupled nature of the chemical system may mean secondary production of $\mathrm{OH}$ (via reactions 14 and 17) with increasing $\mathrm{NO}_{x}$ has offset increased primary loss owing to growing concentrations of reactive anthropogenic VOCs. ${ }^{5}$

\section{Other sources of $\mathrm{HO}_{x}$}

As previously mentioned, there are a number of other potential sources of $\mathrm{HO}_{x}$ in the atmosphere, such as the photolysis of carbonyl compounds produced from the (partial) oxidation of hydrocarbon species. The simplest and most common of these is formaldehyde, which is produced from $\mathrm{CH}_{4}$ oxidation (see Fig. 4), the photolysis of which can produce up to two $\mathrm{HO}_{2}$ radicals viz

$$
\begin{gathered}
\mathrm{HCHO}+h v(\lambda<334 \mathrm{~nm}) \rightarrow \mathrm{H}+\mathrm{HCO} \\
\mathrm{HCHO}+h v \rightarrow \mathrm{H}_{2}+\mathrm{CO} \\
\mathrm{HCO}+\mathrm{O}_{2} \rightarrow \mathrm{HO}_{2}+\mathrm{CO} \\
\mathrm{H}+\mathrm{O}_{2}+\mathrm{M} \rightarrow \mathrm{HO}_{2}+\mathrm{M}
\end{gathered}
$$

Pre-industrial

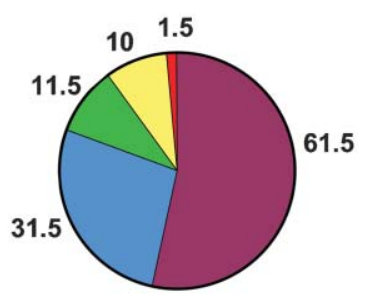

Total $G=116$ Tmol/year

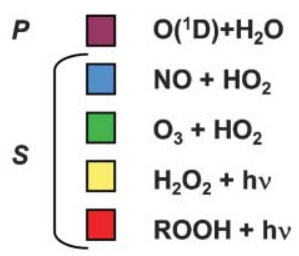

\section{Present}

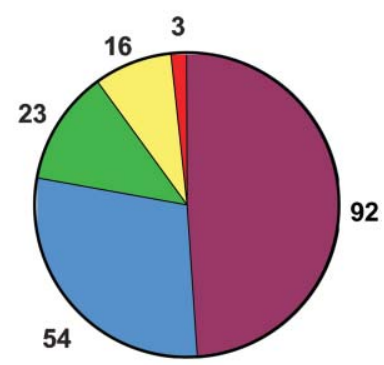

Total $G=188 \mathrm{Tmol} / \mathrm{year}$

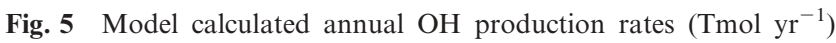
through the main chemical pathways, based on present day and preindustrial emissions of natural and anthropogenic origin. ${ }^{5}$

Photolysis of carbonyls such as acetone have shown indications of being key sources of $\mathrm{HO}_{x}$ in the (upper) free troposphere when it is dry. ${ }^{6}$

Under mainly urban conditions $\mathrm{OH}$ may be formed from secondary sources such as

$$
\mathrm{HONO}+h v(\lambda<400 \mathrm{~nm}) \rightarrow \mathrm{OH}+\mathrm{NO}
$$

where HONO can be emitted in small quantities from automobiles or formed from a number of heterogeneous pathways, ${ }^{7}$ as well as in the gas-phase.

One route of growing importance, particularly in the boundary layer, is production of $\mathrm{HO}_{x}$ from the reactions between ozone and alkenes. The ozonolysis of alkenes can lead to the direct production of the $\mathrm{OH}$ radical at varying yields (between 7-100\%) depending on the structure of the alkene, and is normally accompanied by the co-production of an (organic) peroxy radical. As compared to both the reactions of $\mathrm{OH}$ and $\mathrm{NO}_{3}$ with alkenes, the initial rate of the reaction of ozone with an alkene is relatively slow; this can be offset under regimes where there are high concentrations of alkenes and/or ozone. For example, under typical rural conditions the atmospheric lifetimes $\left(\tau=1 / k_{i}[\mathrm{X}]\right.$, where $\mathrm{X}$ is the radical or ozone) for the reaction of ethene with $\mathrm{OH}, \mathrm{O}_{3}$ and $\mathrm{NO}_{3}$ are 20 hours, 9.7 days and 5.2 months respectively. In contrast, for the same reactants with 2-methyl-2-butene the atmospheric lifetimes are 2.0 hours, 0.9 hours and 0.09 hours.

The mechanism for the reaction of ozone with alkenes was first suggested by Criegee in the late 1940s (for details see ref. 8) and involves the addition of ozone to form a primary ozonide, which rapidly decomposes to form a vibrationally excited carbonyl oxide (Criegee intermediate) and carbonyl products. The Criegee intermediate can then either be collisionally stabilized by a third body (M), or undergo unimolecular decomposition to products. It is now widely believed that alkyl-substituted Criegee intermediates can 
decompose via a vibrationally hot hydroperoxide intermediate to yield an $\mathrm{OH}$ radical, along with another radical species of the general form $R_{1} R_{2} C C(O) R_{3}$, which is expected to react rapidly with $\mathrm{O}_{2}$ to form a peroxy radical $\left(\mathrm{RO}_{2}\right)$ in the atmosphere (e.g. ref. 9). Fig. 6 shows a schematic representation of the ozone-alkene reaction mechanism. The $\mathrm{OH}$ and peroxy radical yield is dependent on the structure and mechanism of the individual alkene-ozone reaction. ${ }^{10}$ Table 3 shows typical $\mathrm{OH}$ yields for the reaction of a range of anthropogenic and biogenic alkenes with ozone.

\section{Overall reaction cycle of $\mathrm{HO}_{\boldsymbol{x}}$}

Fig. 7 shows a schematic representation of the reaction cycle for $\mathrm{HO}_{x}{ }^{11}$ The numbers along the arrows in Fig. 7 are the

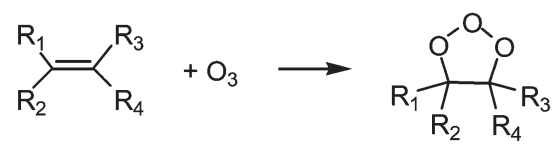

\section{Primary Ozonide}
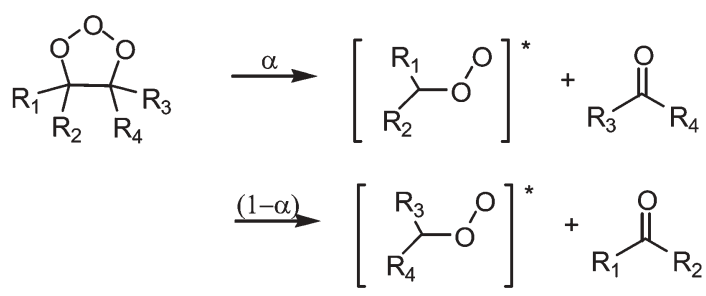

$\left[\underset{\mathrm{R}^{\prime}}{\mathrm{R}} \mathrm{O}^{\mathrm{O}}\right]^{*} \stackrel{\mathrm{M}}{\longrightarrow}$ Stabilisation

$\left[\underset{\mathrm{R}^{\prime}}{\mathrm{R}} \mathrm{O}^{\prime} \mathrm{O}\right]^{*} \longrightarrow$ Decomposition Products

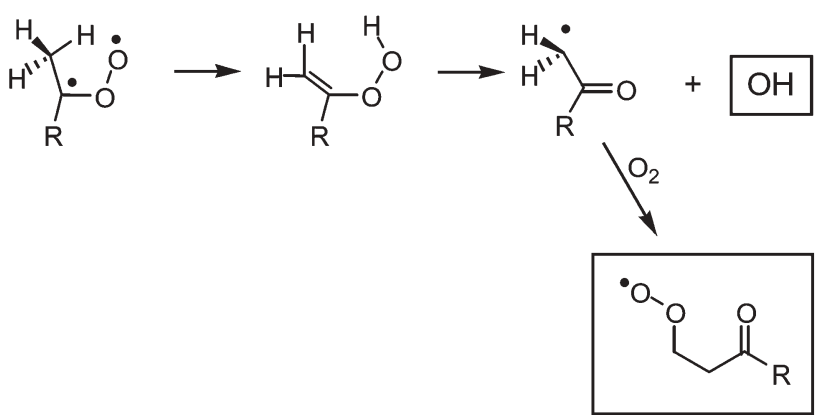

Fig. 6 A schematic representation of the oxidation of an alkene initiated by reaction with ozone. ${ }^{33}$

Table 3 Range of $\mathrm{OH}$ yields from the reaction of ozone with alkenes

\begin{tabular}{ll}
\hline Alkene & OH Yield \\
\hline Ethene & $0.18 \pm 0.06$ \\
Propene & $0.35 \pm 0.07$ \\
Methylpropene & $0.72 \pm 0.12$ \\
$\Delta^{3}$-carene & 1.00 \\
${ }^{a}$ All data taken from ref. 10. & \\
\hline
\end{tabular}

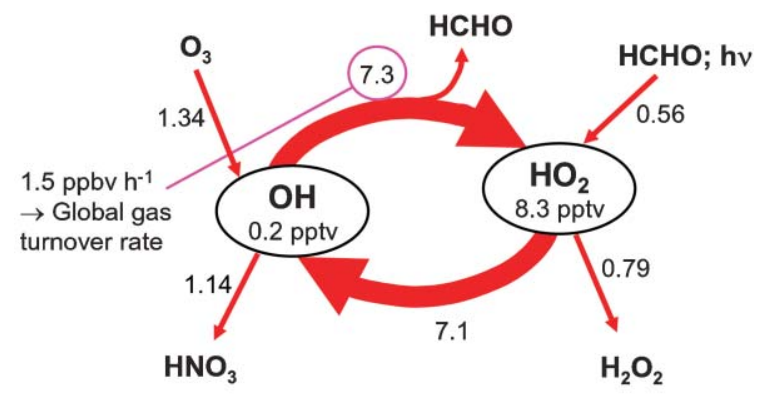

All fluxes in $10^{6}$
molecule $\mathrm{cm}^{-3} \mathrm{~s}^{-1}$
$\mathrm{NO}_{\mathrm{x}}=1 \mathrm{ppbv}$

Fig. 7 Schematic representation of the reaction cycle for $\mathrm{HO}_{x}$. The numbers in the ovals represent the model calculated radical concentrations (in $10^{6}$ molecule $\mathrm{cm}^{-3}$ ) and the numbers along the arrows represent the conversion rates of $\mathrm{HO}_{x}$ (in $10^{6}$ molecule $\mathrm{cm}^{-3} \mathrm{~s}^{-1}$ ). ${ }^{11}$ The model run is for a typical rural background set of atmospheric conditions. Only the major pathways are represented.

modelled conversion rates of $\mathrm{HO}_{x}$ (in molecule $\mathrm{cm}^{-3} \mathrm{~s}^{-1}$ ). All the data are taken from a simple rural background cleanair model. ${ }^{11}$ The relative ratio of $[\mathrm{OH}] /\left[\mathrm{HO}_{2}\right]$ where $[\mathrm{OH}]=$ $4.5 \times 10^{6}$ molecule $\mathrm{cm}^{-3}$ and $\left[\mathrm{HO}_{2}\right]=2 \times 10^{8}$ molecule $\mathrm{cm}^{-3}$ (about 8 pptv) is about $1 / 50$. For $\mathrm{OH}$ production, photolysis of ozone and the subsequent reaction of the photoproducts (reactions 2 and 3) is the main source of primary $\mathrm{OH}$ production $(95 \%)$ with a smaller source coming from $\mathrm{H}_{2} \mathrm{O}_{2}$ photolysis ( $c f$. Table 1). HCHO photolysis represents a small but significant source of $\mathrm{HO}_{2}$ (reaction 20a, 21, 7), thus contributing about $26 \%$ to $\mathrm{HO}_{x}$ production. Formaldehyde can be derived both from methane oxidation (reaction 18 and see Fig. 4) and thus act autocatalytically as a $\mathrm{HO}_{x}$ source (sometimes termed a secondary source) or be directly emitted from vegetation. In steady-state, the net production of $\mathrm{HO}_{x}$ is balanced by the net destruction, the main destruction routes being the formation of $\mathrm{HNO}_{3}$ (responsible for 54\% net destruction of $\mathrm{HO}_{x}$ ), reaction (18) and the formation of peroxides (responsible for $36 \%$ net destruction, reactions (12) and (13)). The chemistry is essentially that of radical chain chemistry with the termination reactions in competition with the $\mathrm{OH} / \mathrm{HO}_{2}$ recycling (see Fig. 1). The overall recycling rate of $7.3 \times 10^{6}$ molecules $\mathrm{cm}^{-3} \mathrm{~s}^{-1}$ equates to an oxidation rate of about $1.5 \mathrm{ppbv} \mathrm{h}^{-1}$. Though this may not seem much, given the size of the atmosphere, the global turn over rate (sometime called oxidation capacity) becomes significant. Division of the $\mathrm{HO}_{2}$ to $\mathrm{OH}$ interconversion rate by the net $\mathrm{HO}_{x}$ loss rate gives the $\mathrm{HO}_{x}$ recycling ratio or chain length. In this case, the model data $^{11}$ gives a value of about four which is typical for the troposphere. Converting this into the corresponding time constants means a $\mathrm{HO}_{x}$ radical is recycled every $28 \mathrm{~s}$ and the mean lifetime of $\mathrm{HO}_{x}$ radical is about $108 \mathrm{~s}$. This lifetime can be equated to the response time of $\mathrm{HO}_{x}$ and thus $\mathrm{OH}$ concentration to changing primary production, despite the lifetime of an individual $\mathrm{OH}$ radical being $0.5 \mathrm{~s}$.

From a consideration of the atmospheric radical chemistry described so far it is clear that the chemistry of nitrogen oxides (radicals in themselves) are an integral part of tropospheric 
oxidation and photochemical processes It is therefore worth considering the effect of changing $\mathrm{NO}_{x}$ on the radical budgets in particular the $\mathrm{OH}$ and $\mathrm{HO}_{2}$ ratio as $\left[\mathrm{NO}_{x}\right]$ controls the partitioning of $\mathrm{HO}_{x}$ between $\mathrm{OH}$ and $\mathrm{HO}_{2}$ and is integrally linked to the production of ozone in the unpolluted atmosphere (see Fate of Peroxy Radicals). The role of $\mathrm{NO}_{x}$ in $\mathrm{HO}_{x}$ partitioning can be illustrated by consideration of the simple interconversion ratio (ICR) between $\mathrm{OH}$ and $\mathrm{HO}_{2}$ (see also Fig. 7)

$$
\frac{\left[\mathrm{HO}_{2}\right]}{[\mathrm{OH}]}=\frac{k_{6}[\mathrm{CO}]+k_{8}\left[\mathrm{CH}_{4}\right]+k_{10}\left[\mathrm{O}_{3}\right]}{k_{14}[\mathrm{NO}]+k_{11}\left[\mathrm{O}_{3}\right]}
$$

where the reaction of $\mathrm{OH}$ with $\mathrm{CO}, \mathrm{CH}_{4}$ or $\mathrm{O}_{3}$ converts $\mathrm{OH}$ into $\mathrm{HO}_{2}$ and the reactions of $\mathrm{HO}_{2}$ with $\mathrm{NO}$ or $\mathrm{O}_{3}$ converts $\mathrm{HO}_{2}$ to $\mathrm{OH} .{ }^{12}$ As $\left[\mathrm{NO}_{x}\right]$ increases the $\mathrm{HO}_{2} / \mathrm{OH}$ ratio decreases; $[\mathrm{OH}]$ increases with increasing $\mathrm{NO}_{x}$, as the reaction between $\mathrm{HO}_{2}$ and $\mathrm{NO}$ (reaction 14) becomes an important secondary source for $\mathrm{OH}$, almost as important as the primary production via reaction of $\mathrm{O}\left({ }^{1} \mathrm{D}\right)$ with water (reactions 2-3). For $\mathrm{HO}_{2}$, as $\left[\mathrm{NO}_{x}\right]$ increases, loss via reaction NO (reaction 14) becomes dominant over loss from the self- and cross- reactions (reactions 12 and 13). This is somewhat of a simplification owing to the role of $\mathrm{RO}_{2}$ as a source of $\mathrm{HO}_{2}$. At higher $\mathrm{NO}_{x}$ levels, the reaction between $\mathrm{OH}$ and $\mathrm{NO}_{2}$ to form $\mathrm{HNO}_{3}$ controls the net loss of $\mathrm{HO}_{x}$ leading to an eventual decrease in $\mathrm{OH}\left(\right.$ and $\mathrm{HO}_{x}$ ). The net effect of these interactions is that $[\mathrm{OH}]$ has a fairly non-linear response to increasing $\mathrm{NO}_{x}$ (see for example ref. 11). Fig. 8 shows a dramatic example of the impact of changing $\mathrm{NO}_{x}$ on $\mathrm{OH}$ and $\mathrm{HO}_{2}$ from urban measurements where $\mathrm{OH}$ is essentially unaffected by the widely changing $\mathrm{NO}_{x}$ and $\mathrm{HO}_{2}$ is suppressed at high $\left[\mathrm{NO}_{x}\right]^{13}$

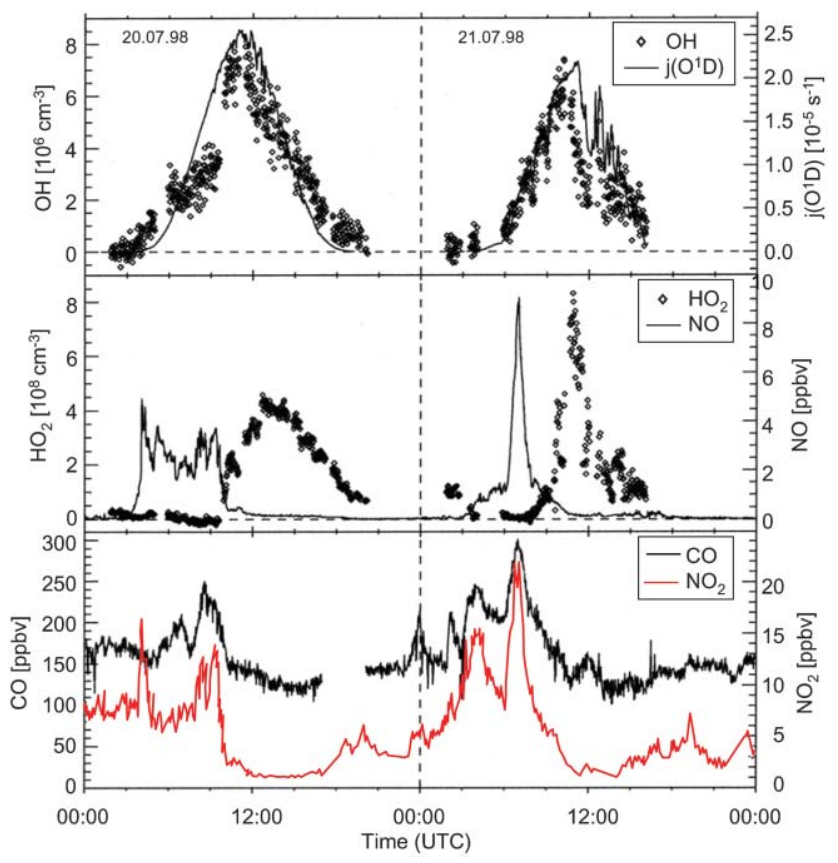

Fig. 8 Measurements of $\mathrm{OH}, \mathrm{HO}_{2}, j\left(\mathrm{O}^{1} \mathrm{D}\right), \mathrm{NO}, \mathrm{NO}_{2}$ and $\mathrm{CO}$ during a summer urban campaign. ${ }^{13}$ The figure demonstrates the dramatic feedback of $\mathrm{NO}_{x}$ on $\mathrm{HO}_{x}$ radicals, the $\left[\mathrm{HO}_{2}\right]$ clearly suppressed at high $\mathrm{NO}_{x}$ while the $[\mathrm{OH}]$ remains largely unaffected.
Fate of peroxy radicals-photochemical production and destruction of ozone

The fate of the peroxy radicals can have a marked effect on the ability of the atmosphere either to produce or to destroy ozone. Photolysis of $\mathrm{NO}_{2}$ and the subsequent reaction of the photoproduct $\mathrm{O}\left({ }^{3} \mathrm{P}\right)$ with $\mathrm{O}_{2}$ (reactions 15 and 16) are the only known way of producing ozone in the troposphere. In the presence of $\mathrm{NO}_{x}$ the following cycle for the production of ozone can take place:

$$
\begin{gathered}
\mathrm{OH}+\mathrm{CO} \rightarrow \mathrm{H}+\mathrm{CO}_{2} \\
\mathrm{H}+\mathrm{O}_{2}+\mathrm{M} \rightarrow \mathrm{HO}_{2}+\mathrm{M} \\
\mathrm{HO}_{2}+\mathrm{NO} \rightarrow \mathrm{OH}+\mathrm{NO}_{2} \\
\mathrm{NO}_{2}+h v \rightarrow \mathrm{O}\left({ }^{3} \mathrm{P}\right)+\mathrm{NO} \\
\mathrm{O}\left({ }^{3} \mathrm{P}\right)+\mathrm{O}_{2}+\mathrm{M} \rightarrow \mathrm{O}_{3}+\mathrm{M} \\
\mathrm{NET}: \mathrm{CO}+2 \mathrm{O}_{2}+h v \rightarrow \mathrm{CO}_{2}+\mathrm{O}_{3}
\end{gathered}
$$

Similar chain reactions can be written for reactions involving $\mathrm{RO}_{2}$. In contrast, when relatively little $\mathrm{NO}_{x}$ is present, as in the remote atmosphere, the following cycle can dominate over ozone production leading to the catalytic destruction of ozone, viz.

$$
\begin{gathered}
\mathrm{OH}+\mathrm{CO} \rightarrow \mathrm{H}+\mathrm{CO}_{2} \\
\mathrm{H}+\mathrm{O}_{2}+\mathrm{M} \rightarrow \mathrm{HO}_{2}+\mathrm{M} \\
\mathrm{HO}_{2}+\mathrm{O}_{3} \rightarrow \mathrm{OH}+2 \mathrm{O}_{2} \\
\mathrm{NET}: \mathrm{CO}+\mathrm{O}_{3} \rightarrow \mathrm{CO}_{2}+\mathrm{O}_{2}
\end{gathered}
$$

Clearly, there is a balance between photochemical ozone production and ozone loss dependent on the concentrations of $\mathrm{HO}_{x}$ and $\mathrm{NO}_{x}$. Fig. 9 shows the dependence of the production of ozone on $\mathrm{NO}_{x}$ taken from a numerical model. There are

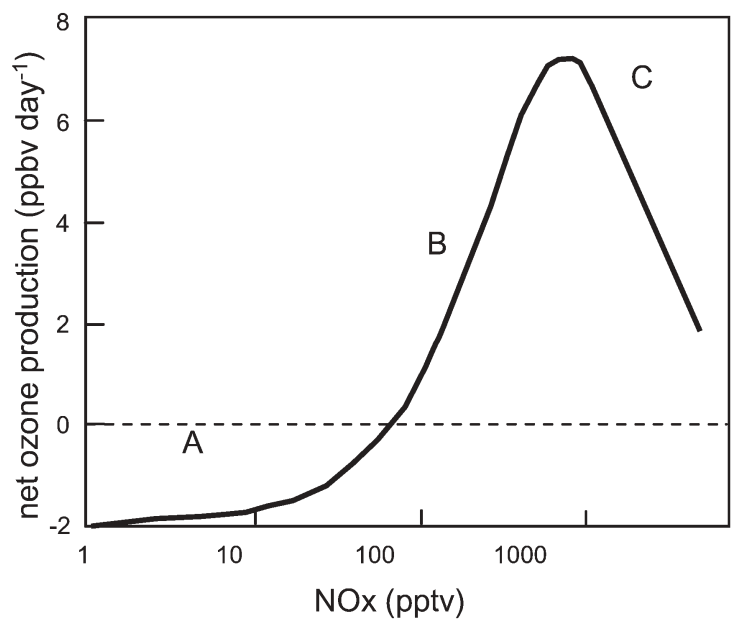

Fig. 9 Schematic representation of the dependence of the net ozone $\left(N\left(\mathrm{O}_{3}\right)\right)$ production (or destruction) on the concentration of $\mathrm{NO}_{x}$. The magnitudes reflect clean free tropospheric conditions. 
distinct regions in terms of $N\left(\mathrm{O}_{3}\right)$ vs. [ $\left.\mathrm{NO}_{x}\right]$ on Fig. 9. For example, in region A the loss of ozone (denoted as $L\left(\mathrm{O}_{3}\right)$ ) is greater than the production of ozone (denoted as $P\left(\mathrm{O}_{3}\right)$ ), hence the net product (denoted as $N\left(\mathrm{O}_{3}\right)$ ) of this process i.e.

$$
N\left(\mathrm{O}_{3}\right)=P\left(\mathrm{O}_{3}\right)-L\left(\mathrm{O}_{3}\right)
$$

leads to a net ozone loss. The photochemical loss of ozone can be represented as

$$
L\left(\mathrm{O}_{3}\right)=\left[\mathrm{O}_{3}\right]\left\{\left(f \cdot j_{2}\left(\mathrm{O}^{1} \mathrm{D}\right)\right)+k_{10}\left[\mathrm{HO}_{2}\right]+k_{11}[\mathrm{OH}]\right\}
$$

where $f$ is the fraction of $\mathrm{O}\left({ }^{1} \mathrm{D}\right)$ atoms that react with water vapour (reaction 3) rather than being deactivated to $\mathrm{O}\left({ }^{3} \mathrm{P}\right)$ (reactions $4+5$ ). Evaluation of eqn. (27) effectively provides a lower limit for the chemical ozone loss rate as it neglects any other potential chemical loss processes for ozone such as cloud chemistry, ${ }^{14} \mathrm{NO}_{3}$ chemistry ${ }^{15}$ or halogen chemistry (see section on halogen chemistry). The balance point, i.e. where $N\left(\mathrm{O}_{3}\right)=0$ is often referred to, somewhat misleadingly, as the compensation point and occurs at a critical concentration of $\mathrm{NO}_{x}$. Above the compensation point $P\left(\mathrm{O}_{3}\right)>L\left(\mathrm{O}_{3}\right)$ and therefore $N\left(\mathrm{O}_{3}\right)$ is positive and the system is forming ozone. The in-situ formation rate for ozone is given approximately by the rate at which the peroxy radicals $\left(\mathrm{HO}_{2}\right.$ and $\left.\mathrm{RO}_{2}\right)$ oxidise $\mathrm{NO}$ to $\mathrm{NO}_{2}$. This is followed by the rapid photolysis of $\mathrm{NO}_{2}$ (reaction 15) to yield the oxygen atom, $\mathrm{O}\left({ }^{3} \mathrm{P}\right)$, required to produce an $\mathrm{O}_{3}$ molecule

$$
P\left(\mathrm{O}_{3}\right)=[\mathrm{NO}] \cdot\left(k_{14}\left[\mathrm{HO}_{2}\right]+\Sigma k_{i}\left[\mathrm{RO}_{2}\right]_{i}\right)
$$

At some concentration of $\mathrm{NO}_{x}$ the system reaches a maximum production rate for ozone at $\mathrm{d} P\left(\mathrm{O}_{3}\right) / \mathrm{d}\left(\mathrm{NO}_{x}\right)=0$ and even though $P\left(\mathrm{O}_{3}\right)$ is still significantly larger than $L\left(\mathrm{O}_{3}\right)$ the net production rate begins to fall off with increasing $\mathrm{NO}_{x}$. Until this maximum is reached the system is said to be $\mathrm{NO}_{x}$ limited with respect to the production of ozone. The turn-over i.e. $\mathrm{d} P\left(\mathrm{O}_{3}\right) / \mathrm{d}\left(\mathrm{NO}_{x}\right)=0$ is caused by the increased competition for $\mathrm{NO}_{x}$ by the reaction

$$
\mathrm{OH}+\mathrm{NO}_{2}+\mathrm{M} \rightarrow \mathrm{HNO}_{3}+\mathrm{M}
$$

In reality, the situation is somewhat more complicated by the presence at high concentrations of $\mathrm{NO}_{x}$ of increased levels of non-methane hydrocarbons (NMHCs), especially in places with urban atmospheric conditions. The oxidation of NMHCs, in common with much of tropospheric oxidation chemistry, is initiated by reaction with $\mathrm{OH}$, leading to the rapid sequence of chain reactions

$$
\begin{gathered}
\mathrm{OH}+\mathrm{RH} \rightarrow \mathrm{R}+\mathrm{H}_{2} \mathrm{O} \\
\mathrm{R}+\mathrm{O}_{2}+\mathrm{M} \rightarrow \mathrm{RO}_{2}+\mathrm{M} \\
\mathrm{RO}_{2}+\mathrm{NO} \rightarrow \mathrm{RO}+\mathrm{NO}_{2} \\
\mathrm{RO} \rightarrow \text { carbonyl products }+\mathrm{HO}_{2} \\
\mathrm{HO}_{2}+\mathrm{NO} \rightarrow \mathrm{OH}+\mathrm{NO}_{2}
\end{gathered}
$$

This cycle is similar to the preceding one for the oxidation of $\mathrm{CO}$, in that it is catalytic with respect to $\mathrm{OH}, \mathrm{R}, \mathrm{RO}$ and $\mathrm{RO}_{2}$, with $\mathrm{HO}_{2}$ acting as the chain propagating radical. The mechanism of reaction (32) is strongly dependent on the structure of RO.

With the involvement of volatile organic compounds (VOCs) in the oxidation chemistry, Fig. 9 represents a 2-D slice through an $n$-dimensional surface where there should be an axis to represent the concentration of VOCs. The peak initial concentrations of ozone generated from a range of initial concentrations of $\mathrm{NO}_{x}$ and VOCs are usually represented as an " $\mathrm{O}_{3}$ isopleth diagram", an example of which is shown in Fig. 10. ${ }^{16}$ In an ozone isopleth diagram, initial mixture compositions giving rise to the same peak $\mathrm{O}_{3}$ concentration are connected by the appropriate isopleth. An isopleth plot shows that ozone production is a highly nonlinear process in relation to $\mathrm{NO}_{x}$ and VOC, but picks out many of the features already highlighted in Fig. 9, i.e. when $\mathrm{NO}_{x}$ is "low" the rate of ozone formation increases with increasing $\mathrm{NO}_{x}$ in a near-linear fashion. On the isopleth, the local maximum in the ozone formation rate with respect to $\mathrm{NO}_{x}$ is the same feature as the turn over in $N\left(\mathrm{O}_{3}\right)$ in Fig. 9. The ridgeline along the local maximum separates two different regimes, the so-called $\mathrm{NO}_{x}$-sensitive regime i.e. $N\left(\mathrm{O}_{3}\right) \propto\left(\mathrm{NO}_{x}\right)$ and the VOC-sensitive (or $\mathrm{NO}_{x}$ saturated regime), i.e. $N\left(\mathrm{O}_{3}\right) \propto$ (VOC) and increases with increasing $\mathrm{NO}_{x}$. The relationship between $\mathrm{NO}_{x}$, VOCs and ozone embodied in the isopleth diagram indicates one of the problems in the development of air quality policy with respect to ozone. Reductions in VOC are only effective in reducing ozone under VOC-sensitive chemistry (High $\mathrm{NO}_{x}$ ) and reductions in $\mathrm{NO}_{x}$ will only be effective if $\mathrm{NO}_{x}$-sensitive chemistry predominates and may actually increase ozone in VOC-sensitive regions. In general, as an airmass moves away from emission sources, e.g. in an urban region, the chemistry tends to move from VOC-sensitive to $\mathrm{NO}_{x}$-sensitive chemistry. It is worth noting that Fig. 9, which is

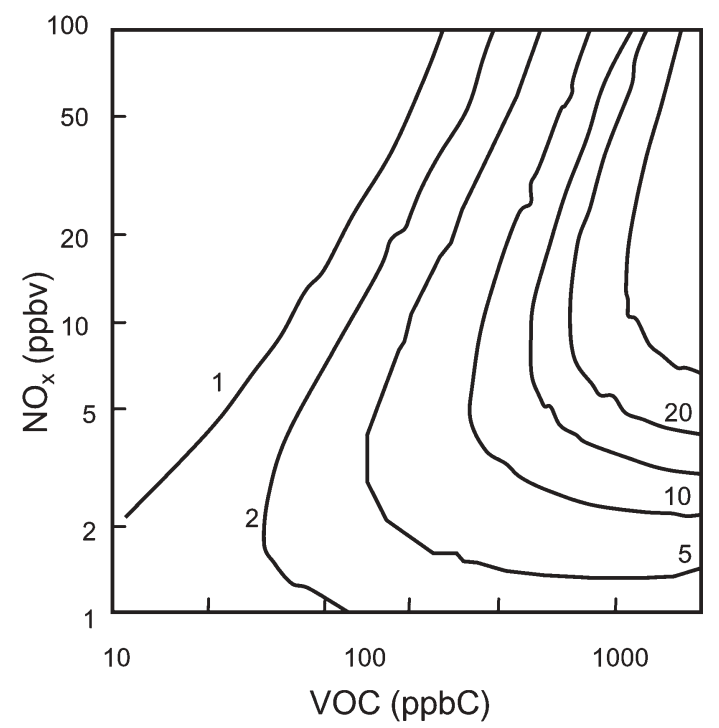

Fig. 10 Isopleths giving net rate of ozone production $\left(\mathrm{ppb} \mathrm{h}^{-1}\right)$ as a function of VOC (ppbC) and $\mathrm{NO}_{x}$ (ppbv) for mean summer daytime meteorology and clear skies under urban conditions. ${ }^{16}$ 
generated from a model, has an experimental counterpart, Fig. 13, which is dealt with later.

Another way of thinking of the ability of the atmosphere to make ozone is that the propensity for ozone formation is essentially proportional to the chain-length of the cycle, i.e. the number of free radical propagated cycles before termination (see Fig. 1). Therefore, the ozone production efficiency becomes a balance between propagation of the free radical interconversion cycle versus the rate of termination of the cycle. Under VOC-limited conditions, i.e. when $\left[\mathrm{NO}_{x}\right]$ vs. [VOC] is high, the competing chain propagation and termination reactions are going to be

$$
\mathrm{OH}+\mathrm{RH} \rightarrow \mathrm{R}+\mathrm{H}_{2} \mathrm{O}
$$

and

$$
\mathrm{OH}+\mathrm{NO}_{2}+\mathrm{M} \rightarrow \mathrm{HNO}_{3}+\mathrm{M}
$$

where reaction (29) will lead to production of ozone and reaction (19) will lead to termination of the $\mathrm{HO}_{x}$ (and $\mathrm{NO}_{x}$ ) chemistry. In the balance between these two reactions lies the problem of VOC $v s \mathrm{NO}_{x}$ control in that reduction of VOC may move the system into an ozone production regime. At high $[\mathrm{VOC}] /\left[\mathrm{NO}_{x}\right]$ ratios or $\mathrm{NO}_{x}$-limited regimes, the dominant chain terminating reactions are the peroxy radical selfand cross-reactions to form peroxides (Reactions 12 and 13). Therefore, the ozone formation chain length is determined by the competition between the reactions of peroxy radicals and $\mathrm{NO}$ and the peroxy radical termination reactions. As shown in Fig. 9 this illustrates the direct dependence of $N\left(\mathrm{O}_{3}\right)$ on $\left[\mathrm{NO}_{x}\right]$.

\section{Experimental evidence}

The test of the chemistry and theory developed to date must lie in the measurement of radical chemistry in the field under a range of atmospheric conditions. It is not within the scope of this review to overview all radical measurements made in the atmosphere. A series of indicative examples have been chosen to illustrate the chemistry detailed in this review and place it within an atmospheric context.

An elegant piece of experimental evidence for the photochemical destruction of ozone and the role of radicals in in-situ photochemistry comes from studies in the remote marine boundary layer over the southern ocean at Cape Grim, Tasmania $\left(41^{\circ} \mathrm{S}\right) .{ }^{17}$ In the marine boundary layer (MBL), the photochemical processes are coupled to physical processes that affect the observed ozone concentrations, namely deposition to the available surfaces and entrainment from the free troposphere. The sum of these processes can be represented in the form of an ozone continuity equation viz.

$$
\frac{\mathrm{d}\left[\mathrm{O}_{3}\right]}{\mathrm{d} t}=C+\frac{E_{\mathrm{v}}\left(\left[\mathrm{O}_{3}\right]_{\mathrm{ft}}-\left[\mathrm{O}_{3}\right]\right)}{H}+\frac{v_{\mathrm{d}}\left[\mathrm{O}_{3}\right]}{H}
$$

where $C$ is a term representative of the photochemistry (the net result of production, $P\left(\mathrm{O}_{3}\right)$, minus destruction, $L\left(\mathrm{O}_{3}\right)$ viz. eqn. (26)), $E_{\mathrm{v}}$ is the entrainment velocity, $\left[\mathrm{O}_{3}\right]_{\mathrm{ft}}$ is the concentration of free-tropospheric ozone, $v_{\mathrm{d}}$ is the dry deposition velocity and $H$ the height of the boundary layer. In general, the marine boundary layer is particularly suitable for making photochemical measurements owing to its stable and chemically simple nature. Fig. 11 shows the average diurnal cycle of ozone and total peroxide (mainly $\mathrm{H}_{2} \mathrm{O}_{2}$ ) in clean oceanic air as measured at Cape Grim during January 1992. During the sunlit hours an ozone loss of about 1.6 ppbv occurs between mid-morning and late afternoon. This loss of ozone is followed by an overnight replenishment to a similar starting point. In contrast, the peroxide concentration decreases overnight from 900 pptv to 600 pptv and then increases from 600 pptv to 900 pptv between mid morning and late afternoon. It is worth noting that the magnitude of this anti-correlation of ozone and peroxide is dependent on season. The daytime anti-correlation between $\mathrm{O}_{3}$ and peroxide can be interpreted as experimental evidence for the photochemical destruction of ozone, as the ozone is destroyed via reactions $(2,10,11)$ while simultaneously peroxide is formed from chemistry involving the oddhydrogen radicals $\mathrm{OH}$ and $\mathrm{HO}_{2}$ (reactions 12 and 13). The night-time replenishment of ozone is caused by entrainment of ozone from the free troposphere into the boundary layer. The overnight loss of peroxide is due to deposition over the sea surface (and heterogeneous loss to the aerosol surface), as peroxide has a significant physical loss rate, in contrast to ozone which does not. Therefore, the daytime anti-correlation of ozone and peroxide is indicative of the net photochemical destruction of ozone.

If the theoretical framework of eqn. (33) is coupled to a suite of measured data, ${ }^{18}$ seasonal estimates of the main contributing processes for the control of ozone in the remote marine boundary layer can be made (see Table 4). There is clear evidence that in the remote MBL the degree of photochemistry determines the lower limit of the ozone concentration, while entrainment across the concentration gradient between the free troposphere and the MBL controls the upper bound. That is, in summer when photochemistry is at a maximum, the ozone concentration is at its lowest value. By contrast, during winter when photochemistry is at a minimum, boundary layer ozone values approach lower free tropospheric values. As can be seen from the data in Table 4, photochemistry as driven by the radicals is the most important ozone-destruction process in the

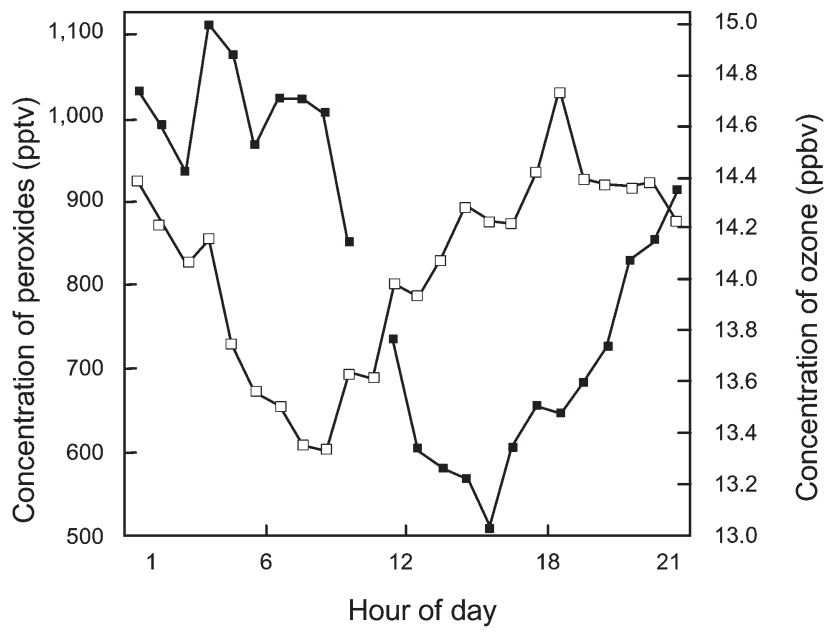

Fig. 11 Average diurnal cycles for peroxide (open squares) and ozone (filled) squares) in baseline air at Cape Grim, Tasmania $\left(41^{\circ} \mathrm{S}\right)$ for January $1992 .{ }^{17}$ 
Table 4 Calculated average ozone removal and addition rates according to pathway ppbv day ${ }^{-1}$ (upper part) and fractional contributions to overall production or destruction pathways (lower part) on a seasonal basis from measurements made in the marine boundary layer at Cape Grim, Tasmania (after ref 18)

\begin{tabular}{|c|c|c|c|c|}
\hline \multirow[t]{2}{*}{ Pathway } & \multicolumn{2}{|l|}{$\mathrm{O}_{3}$ removal } & \multicolumn{2}{|l|}{$\mathrm{O}_{3}$ addition } \\
\hline & Photochemistry $^{a}$ & Deposition & Photochemistry $^{b}$ & Entrainment \\
\hline Jan.-Feb. (Summer) & 1.19 & 0.18 & 0.56 & 2.1 \\
\hline \multirow{2}{*}{ Aug.-Sep. (Winter) } & 0.61 & 0.35 & 0.29 & 0.1 \\
\hline & Photochemistry & Deposition & Photochemistry & Entrainment \\
\hline Jan.-Feb. (Summer) & $87 \%$ & $13 \%$ & $21 \%$ & $79 \%$ \\
\hline Aug.-Sep. (Winter) & $64 \%$ & $36 \%$ & $74 \%$ & $26 \%$ \\
\hline
\end{tabular}

clean marine boundary layer on a seasonal basis. Although entrainment is the dominant ozone-addition process during summer, once the differential between boundary layer and lower free troposphere ozone is reduced, the small photochemical production term becomes the dominant ozone source during winter.

With the integral link between radicals and ozone, one of the interesting scientific questions has been the relative role of photochemistry and transport in the control of ozone during the winter-spring transition. ${ }^{19}$ As part of the TOPSE (Tropospheric Ozone Production about the Spring Equinox) experiment a series of measurements of radical and tracer species were made from an airborne platform. ${ }^{20}$ Radical measurements ${ }^{21}$ coupled to the relevant source gases and actinic flux can be used to diagnose the fast photochemistry. Using a steady-state model constrained by the measurements, estimates were made of the radical production and loss budgets. Fig. 12 shows the altitude-time profiles of the total $\mathrm{HO}_{x}+\mathrm{RO}_{x}$ sources and the fraction of the relevant source and sinks processes for the sampled region between $60^{\circ}$ and $85^{\circ} \mathrm{N} .^{21} \mathrm{It}$ is clear that radicals can be produced from a variety of photolytic and thermal reactions (See Fig. 1), the relative importance of which depends on the concentration of precursor species, light levels, temperature and humidity. The data in Fig. 12 shows very low initial $\mathrm{HO}_{x}$ and $\mathrm{RO}_{x}$ production and loss rates that increase systematically with season. One noticeable feature of these data is the low contribution of the primary $\mathrm{OH}$ formation channel from the reaction of $\mathrm{O}\left({ }^{1} \mathrm{D}\right)$ and water (reactions 2 and 3, Fig. 12b) throughout the measurement period at high latitudes. Interestingly, both $\mathrm{HCHO}$ (and $\mathrm{H}_{2} \mathrm{O}_{2}$ ) photolysis are significant radical sources at mid to high altitudes $(>4 \mathrm{~km})$ at high latitudes over the winter-spring transition (Fig. 12c).

With respect to radical loss, the main loss processes are either radical-radical recombinations or radical- $\mathrm{NO}_{y}(\mathrm{NO}$, $\mathrm{NO}_{2}$ and $\mathrm{HNO}_{3}$ ) reactions (see Fig. 1). As can be seen in Fig. 12d-f the bulk of the loss is via reactions (12) and (13), the self and cross-reactions for $\mathrm{HO}_{2}$ and $\mathrm{CH}_{3} \mathrm{O}_{2}$. The $\mathrm{HO}_{x}+\mathrm{RO}_{x}$ radical loss via radical- $\mathrm{NO}_{y}$ reactions are of the order of $5-10 \%$ of the total loss. With the relatively small contribution of $\mathrm{O}\left({ }^{1} \mathrm{D}\right)$ plus water to $\mathrm{OH}$ production $(10 \%)$ under the conditions encountered $\mathrm{OH}$ sources were dominated equally by both the reaction between $\mathrm{HO}_{2}$ and $\mathrm{NO}(42 \%)$ (reaction 14) and surprisingly the reaction between $\mathrm{HO}_{2}$ and $\mathrm{O}_{3}(43 \%)$ (reaction 10). The mean recycling chain length for all the data was of the order of 2 . The radical and tracer data can be used to map the photochemical production of ozone through the season and the results indicate that the ozone budget is strongly dependent on latitude and altitude. In the region 60 $90^{\circ} \mathrm{N}, 0.1-0.4 \mathrm{ppbv} \mathrm{day}^{-1}$ is transported into the region (from mid-latitudes) while the gross ozone production ( $c f$. eqn. 26) rates in the same region are $0.7-0.9 \mathrm{pbbv}^{-1}{ }^{-1}$ emphasising that the control of spring ozone at mid to high latitudes is a combination of chemistry and transport.

An example of the experimental determination of the relationships between radicals, $P\left(\mathrm{O}_{3}\right)$ and $\mathrm{NO}_{x}$ is shown in Fig. 13 ( $c f$. Fig. 9): a comparison of observed ozone production rates $\left(P\left(\mathrm{O}_{3}\right)\right)$ and concentrations of $\mathrm{HO}_{2}$ and $\mathrm{OH}$ from the NASA SONEX mission ${ }^{22}$ plotted as a function of $\mathrm{NO}_{x}$. The data were taken from a suite of aircraft measurements between $8-12 \mathrm{~km}$ altitude at latitudes between $40-60^{\circ} \mathrm{N}$. The model data suggest that $P\left(\mathrm{O}_{3}\right)$ becomes independent of $\mathrm{NO}_{x}$ above $70 \mathrm{pptv}$ and the turn-over point into a $\mathrm{NO}_{x}$-saturated regime occurs at about 300 pptv. The bulk of the experimental observations below $\left[\mathrm{NO}_{x}\right.$ ] levels of 300 pptv fit with the $P\left(\mathrm{O}_{3}\right)$ dependency predicted by the model, but above $\left[\mathrm{NO}_{x}\right] \sim 300$ pptv $P\left(\mathrm{O}_{3}\right)$, computed from the measured $\mathrm{HO}_{2}$ and $\mathrm{NO}$, continues to increase with $\mathrm{NO}_{x}$, suggesting a $\mathrm{NO}_{x}$-limited regime. An interesting feature of the dry upper troposphere in relation to radical formation is the role of acetone as a radical source ${ }^{5,22,23}$ (See Table 1).

From the preceding discussion it can be seen that the involvement of $\mathrm{HO}_{x}$ radical chemistry in gas-phase tropospheric chemistry potentially has several significant consequences:

a) The fate of $\mathrm{OH}$ is intrinsically linked to the control of atmospheric composition for many trace gases.

b) $\mathrm{OH}$ initiated oxidation can produce a wide-range of (partially) oxidized intermediates that can have a wide range of atmospheric lifetimes and impacts.

c) The fate of the peroxy radicals controls tropospheric ozone production and destruction.

In turn the fate of the $\mathrm{HO}_{x}$ radicals have wider implications in

a) Radiative forcing through the control of the lifetime of climate gases, e.g. $\mathrm{CH}_{4}$.

b) Air quality, the formation of ground level ozone, photochemical smog and secondary organic aerosols. ${ }^{24}$ This may in itself impact on human and plant health.

c) Acid rain, through the formation of acid elements, e.g. $\mathrm{HNO}_{3}$ (which is about $33 \%$ of the total potential acidity). 
a)

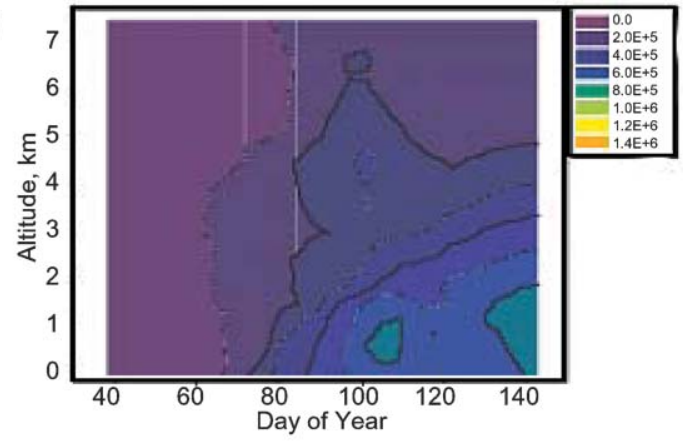

b)

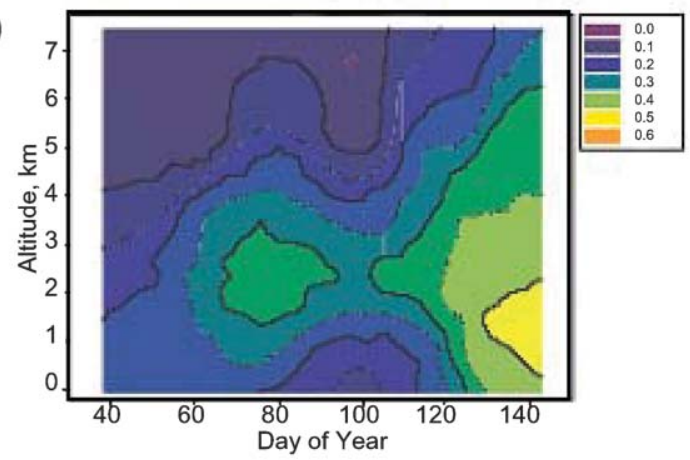

c)

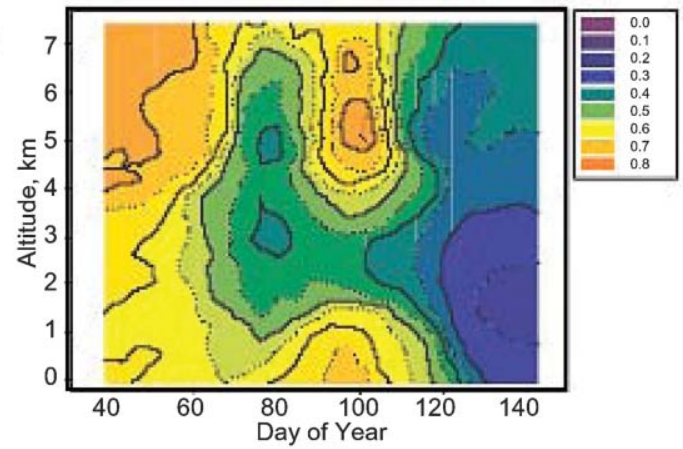

d)

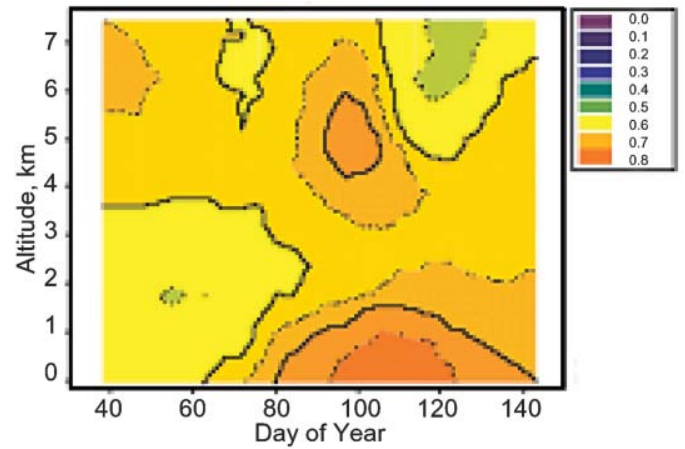

e)

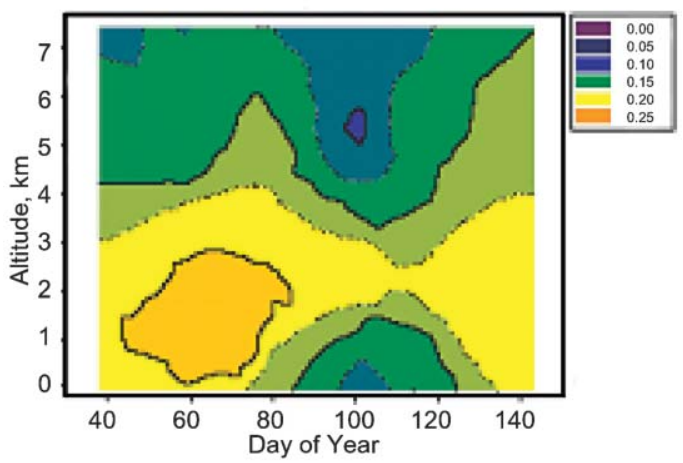

f)

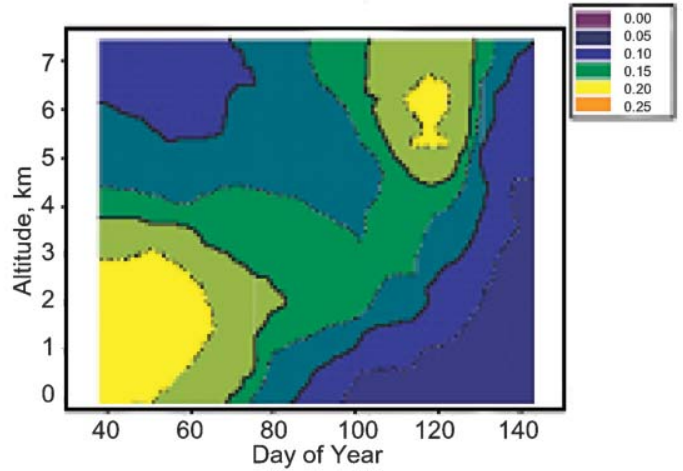

Fig. 12 Altitude time-profiles of the total $\mathrm{HO}_{x}+\mathrm{RO}_{x}$ sources and loss from an observationally constrained steady-state model for measurements between 60 and $85^{\circ} \mathrm{N}$ around the spring equinox. ${ }^{21}$ Panel a) is the total $\mathrm{HO}_{x}+\mathrm{RO}_{x}$ source rate, b) the fraction of the source owing to the reaction of $\mathrm{O}\left({ }^{1} \mathrm{D}\right)$ with water, c) the fraction of the source owing to $\mathrm{HCHO}$, the fraction of the $\mathrm{HO}_{x}+\mathrm{RO}_{x}$ loss owing to the reaction d) between $\mathrm{HO}_{2}$ and $\mathrm{HO}_{2}$, e) between $\mathrm{HO}_{2}$ and $\mathrm{CH}_{3} \mathrm{O}_{2}$ and $\mathrm{f}$ ) between $\mathrm{HO}_{2}$ and $\mathrm{RO}_{2}\left(\operatorname{not} \mathrm{CH}_{3} \mathrm{O}_{2}\right.$ ).

\section{Night-time chemistry - the nitrate radical $\left(\mathrm{NO}_{3}\right)$}

Not all atmospheric radical chemistry is initiated in the daytime. Night-time chemistry does not lead to the production of ozone, in fact the opposite, but has importance owing to the potential for the production of secondary pollutants. In the troposphere, the main night-time oxidant is thought to be the nitrate radical $\left(\mathrm{NO}_{3}\right)$ formed by the relatively slow oxidation of $\mathrm{NO}_{2}$ by $\mathrm{O}_{3}$, viz.

$$
\mathrm{NO}_{2}+\mathrm{O}_{3} \rightarrow \mathrm{NO}_{3}+\mathrm{O}_{2}
$$

The time constant for reaction (34) is of the order of 15 hours at an ozone concentration of $30 \mathrm{ppbv}$ and $T=290 \mathrm{~K}$. Other sources include

$$
\mathrm{N}_{2} \mathrm{O}_{5}+\mathrm{M} \rightarrow \mathrm{NO}_{3}+\mathrm{NO}_{2}+\mathrm{M}
$$

but as $\mathrm{N}_{2} \mathrm{O}_{5}$ is formed from

$$
\mathrm{NO}_{3}+\mathrm{NO}_{2}+\mathrm{M} \rightarrow \mathrm{N}_{2} \mathrm{O}_{5}+\mathrm{M}
$$

the two species act in a coupled manner. Dinitrogen pentoxide, $\mathrm{N}_{2} \mathrm{O}_{5}$, is potentially an important product as it can react heterogeneously with water to yield $\mathrm{HNO}_{3}$. During the daytime the $\mathrm{NO}_{3}$ radical is rapidly photolysed as it strongly absorbs in the visible, viz.

$$
\begin{gathered}
\mathrm{NO}_{3}+h v \rightarrow \mathrm{NO}+\mathrm{O}_{2} \\
\mathrm{NO}_{3}+h v \rightarrow \mathrm{NO}_{2}+\mathrm{O}\left({ }^{3} \mathrm{P}\right)
\end{gathered}
$$

having a lifetime in the region of $5 \mathrm{~s}$ for overhead sun and clear sky conditions. The nitrate radical reacts rapidly with NO

$$
\mathrm{NO}_{3}+\mathrm{NO} \rightarrow \mathrm{NO}_{2}+\mathrm{NO}_{2}
$$




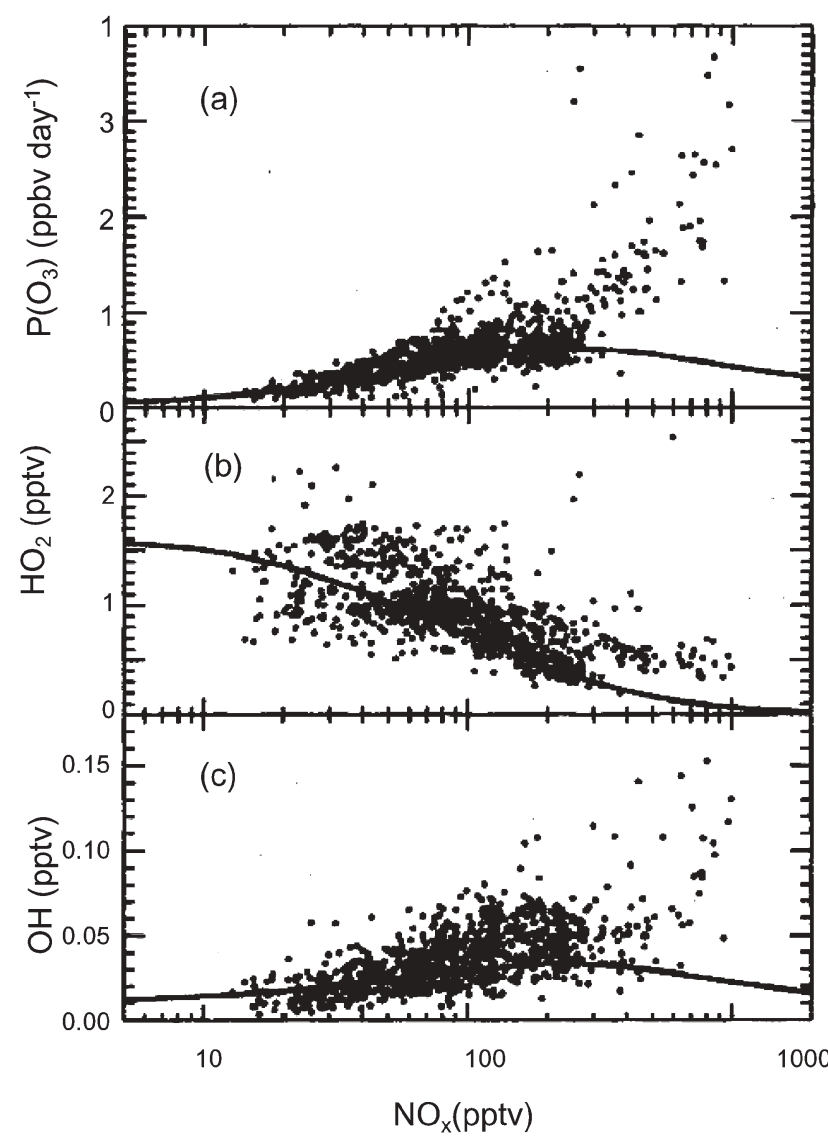

Fig. 13 Observed ozone production rates $\left(P\left(\mathrm{O}_{3}\right)\right)$ and concentrations of $\mathrm{HO}_{2}$ and $\mathrm{OH}$ during SONEX (8-12 km altitude, $40-60^{\circ} \mathrm{N}$ latitude) plotted as a function of the $\mathrm{NO}_{x}$ concentration $\left(\mathrm{NO}_{x}=\right.$ observed $\mathrm{NO}+$ modelled $\mathrm{NO}_{2}$ ). The observed rates and concentrations are averaged over 24 hours, using diel averaging factors obtained from a locally constrained steady-state box model. The lines on the three panels correspond to model-calculated values for median upper tropospheric conditions as encountered during SONEX. ${ }^{22}$

which can have significant daytime concentrations in contrast to the night-time, where away from strong source regions the NO concentrations should be near zero. Under highly polluted conditions, it is possible for $\mathrm{NO}_{3}$ to persist during the day. ${ }^{25}$

The nitrate radical has a range of reactivity towards volatile organic compounds. The nitrate radical is highly reactive towards certain unsaturated hydrocarbons such as isoprene, a variety of butenes and monoterpenes, as well as reduced sulfur compounds such as dimethyl sulfide (DMS). In the case of DMS, if the $\mathrm{NO}_{2}$ concentration is $60 \%$ that of DMS then $\mathrm{NO}_{3}$ is a more important oxidant than $\mathrm{OH}$ for DMS in the marine boundary layer. ${ }^{26}$ In general, $\mathrm{NO}_{3}$ abstraction reactions of the type

$$
\mathrm{NO}_{3}+\mathrm{RH} \rightarrow \mathrm{HNO}_{3}+\mathrm{R}
$$

are relatively slow, with the alkyl radical reacting with oxygen under atmospheric conditions to form a peroxy radical. In the case of $\mathrm{RH}$ being an aldehyde, acyl products will form acylperoxy radicals (R.CO. $\mathrm{O}_{2}$ ), potential sources of peroxyacylnitrates. In contrast, the reaction of $\mathrm{NO}_{3}$ with alkenes occurs by an addition mechanism, initiating a complex chemistry involving nitro-oxy substituted organic radicals, which can either regenerate $\mathrm{NO}_{2}$ or produce comparatively stable bifunctional organic nitrate products. ${ }^{27}$ For example, the products derived from the reaction of $\mathrm{NO}_{3}$ with propene in the presence of $\mathrm{O}_{2}$ and $\mathrm{NO}_{x}$ include $\mathrm{CH}_{3} \mathrm{CHO}, \mathrm{HCHO}$, 1,2-propanediol dinitrate (PDDN), nitroxyperoxypropyl nitrate (NPPN) and $\alpha$-(nitrooxy)acetone. ${ }^{9,28}$ The reaction channel that produces the nitrated acetones also yields peroxy radicals, leading to the potential for a night-time source of $\mathrm{OH}$, either by reaction $\left(\mathrm{HO}_{2}\right.$ $+\mathrm{O}_{3}$ ) or by the direct reaction of the peroxy radical with $\mathrm{NO}_{3}$. For the reaction of $\mathrm{NO}_{3}$ with propene, the initial addition can take place at either end of the double bond, viz.

$$
\begin{aligned}
& \mathrm{NO}_{3}+\mathrm{CH}_{2}=\mathrm{CHCH}_{2}+\mathrm{M} \rightarrow \mathrm{CH}_{2} \mathrm{CHCH}_{2}\left(\mathrm{ONO}_{2}\right)+\mathrm{M} \\
& \mathrm{NO}_{3}+\mathrm{CH}_{2}=\mathrm{CHCH}_{2}+\mathrm{M} \rightarrow \mathrm{CH}_{2} \mathrm{CH}\left(\mathrm{ONO}_{2}\right) \mathrm{CH}_{2}+\mathrm{M}
\end{aligned}
$$

The reaction can then proceed by the mechanism shown schematically in Fig. 14. The ratio of final products is dependent on the structure of the individual alkenes, temperature and pressure. In general, for branched alkenes, there is significant regeneration of $\mathrm{NO}_{x}$ and production of unsubstituted carbonyl products while comparatively they are a minor source of $\mathrm{HO}_{x} \cdot{ }^{27}$ For the less alkyl substituted alkenes, there is a greater yield of $\mathrm{HO}_{x}$ and bifunctional organic nitrate products but a lesser regeneration of $\mathrm{NO}_{x}$. Therefore, depending on the mix of hydrocarbons, $\mathrm{NO}_{3}$ chemistry can act to either recycle $\mathrm{NO}_{x}$ at night, therefore inhibiting the formation of nitrate aerosol or form $\mathrm{HNO}_{3}$ and potentially lead to the generation of a night-time source of $\mathrm{HO}_{x}$. Fig. 15 provides a simplified summary of the relevant night-time chemistry involving the nitrate radical.

One important difference between $\mathrm{NO}_{3}$ chemistry and daytime $\mathrm{OH}$ chemistry is that $\mathrm{NO}_{3}$ can initiate, but not catalyse, the removal of organic compounds. Therefore its concentration can be suppressed by the presence of fastreacting (with respect to $\mathrm{NO}_{3}$ ) organic compounds.

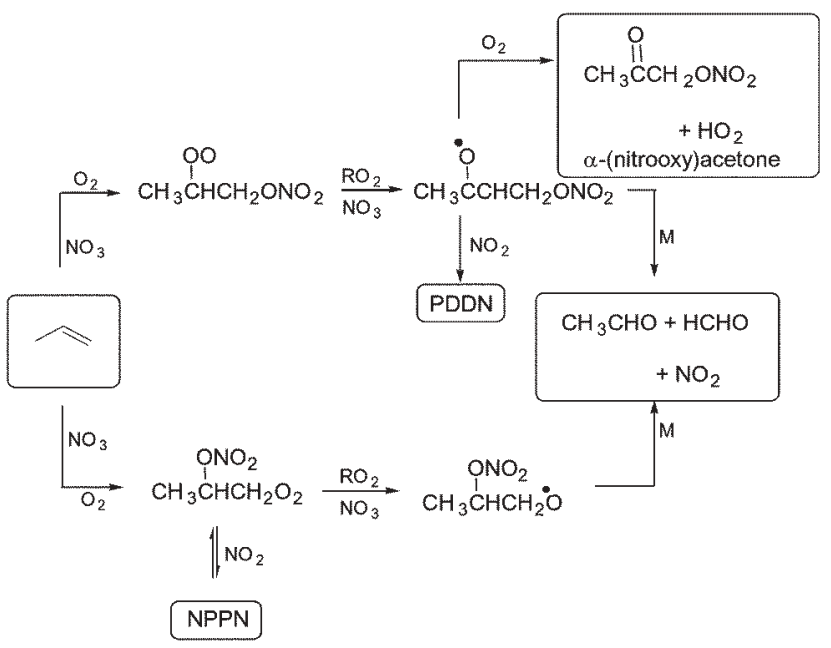

Fig. 14 A schematic representation of the chain propagation reactions in the $\mathrm{NO}_{3}$ radical initiated oxidation of propene. ${ }^{27}$ 


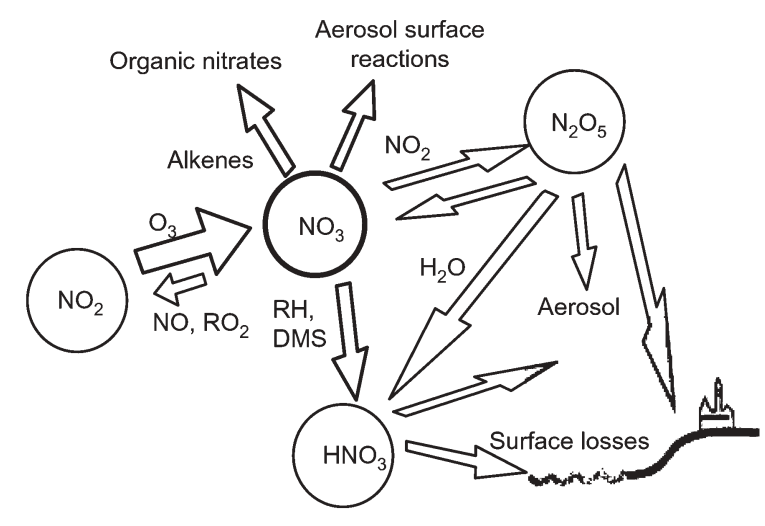

Fig. 15 A simplified reaction scheme for night-time chemistry involving the nitrate radical. ${ }^{26}$

\section{Experimental evidence}

Evidence for the role of $\mathrm{NO}_{3}$ in night-time oxidation chemistry has come from a number of experimental based studies [refs. 26 and 27 and references therein]. The nitrate radical was first observed in the atmosphere by Platt et al. ${ }^{29}$ and Noxon et $a l^{30}$ in the 1980s. Significant $\mathrm{NO}_{3}$ concentrations have been detected over a wide range of atmospheric conditions, indicating a potential role for $\mathrm{NO}_{3}$ in oxidation chemistry over large regions of the atmosphere. ${ }^{27}$ The atmospheric lifetime of $\mathrm{NO}_{3}$ can be estimated using the steady-state approximation to be

$$
\tau\left(\mathrm{NO}_{3}\right)=\frac{\left[\mathrm{NO}_{3}\right]}{k_{34}\left[\mathrm{NO}_{2}\right]\left[\mathrm{O}_{3}\right]}
$$

A useful quantity with which to compare this with is the reciprocal of the lifetime calculated from the sum of the first order loss processes involving $\mathrm{NO}_{3}$ and $\mathrm{N}_{2} \mathrm{O}_{5}$

$$
\begin{gathered}
\tau\left(\mathrm{NO}_{3}\right)^{-1} \geqslant \Sigma_{i} k_{\left(\mathrm{NO}_{3}+\mathrm{HC}_{i}\right)}\left[\mathrm{HC}_{i}\right]+k_{\left(\mathrm{NO}_{3}+\mathrm{DMS}\right)}[\mathrm{DMS}]+k_{\mathrm{het}}\left(\mathrm{NO}_{3}\right) \\
+\left(k^{\mathrm{I}}\left[\mathrm{H}_{2} \mathrm{O}\right]+k^{\mathrm{II}}\left[\mathrm{H}_{2} \mathrm{O}\right]^{2}+k_{\mathrm{het}}\left(\mathrm{N}_{2} \mathrm{O}_{5}\right)\right) \cdot K_{35}\left[\mathrm{NO}_{2}\right]
\end{gathered}
$$

where the pseudo first-order loss rates over the $i$ reactive hydrocarbons are summed and $k^{\mathrm{I}}$ and $k^{\mathrm{II}}$ are the first- and second-order components with respect to $\mathrm{H}_{2} \mathrm{O}$ of the reaction

$$
\mathrm{N}_{2} \mathrm{O}_{5}+\mathrm{H}_{2} \mathrm{O} \rightarrow 2 \mathrm{HNO}_{3}
$$

$k_{\text {het }}\left(\mathrm{NO}_{3}\right)$ and $k_{\text {het }}\left(\mathrm{N}_{2} \mathrm{O}_{5}\right)$ are the heterogeneous loss rates for these species and $K_{35}$ is the equilibrium constant for reactions $(35+36)$. Fig. 16 shows the observed lifetime of $\mathrm{NO}_{3}$ in the marine boundary layer at Mace Head, Ireland ${ }^{26}$ segregated by arrival wind sector. Mace Head experiences a range of air masses from clean marine air to European continental outflow. The measured $\mathrm{NO}_{3}$ lifetime varies from 2 minutes to 4 hours (See Fig. 16). An assessment of the parameters controlling $\mathrm{NO}_{3}$ atmospheric lifetime ( $c f$. eqn. 44) highlights that under the conditions encountered the lifetime of $\mathrm{NO}_{3}$ chemistry is very sensitive to DMS and NMHC chemistry in clean marine air. However, in more polluted air the terms involving the indirect loss of $\mathrm{N}_{2} \mathrm{O}_{5}$ either in the gas-phase with $\mathrm{H}_{2} \mathrm{O}$ or through uptake on aerosol tends to dominate.

There is a growing body of observational evidence for the generation of peroxy radicals during the night under polluted
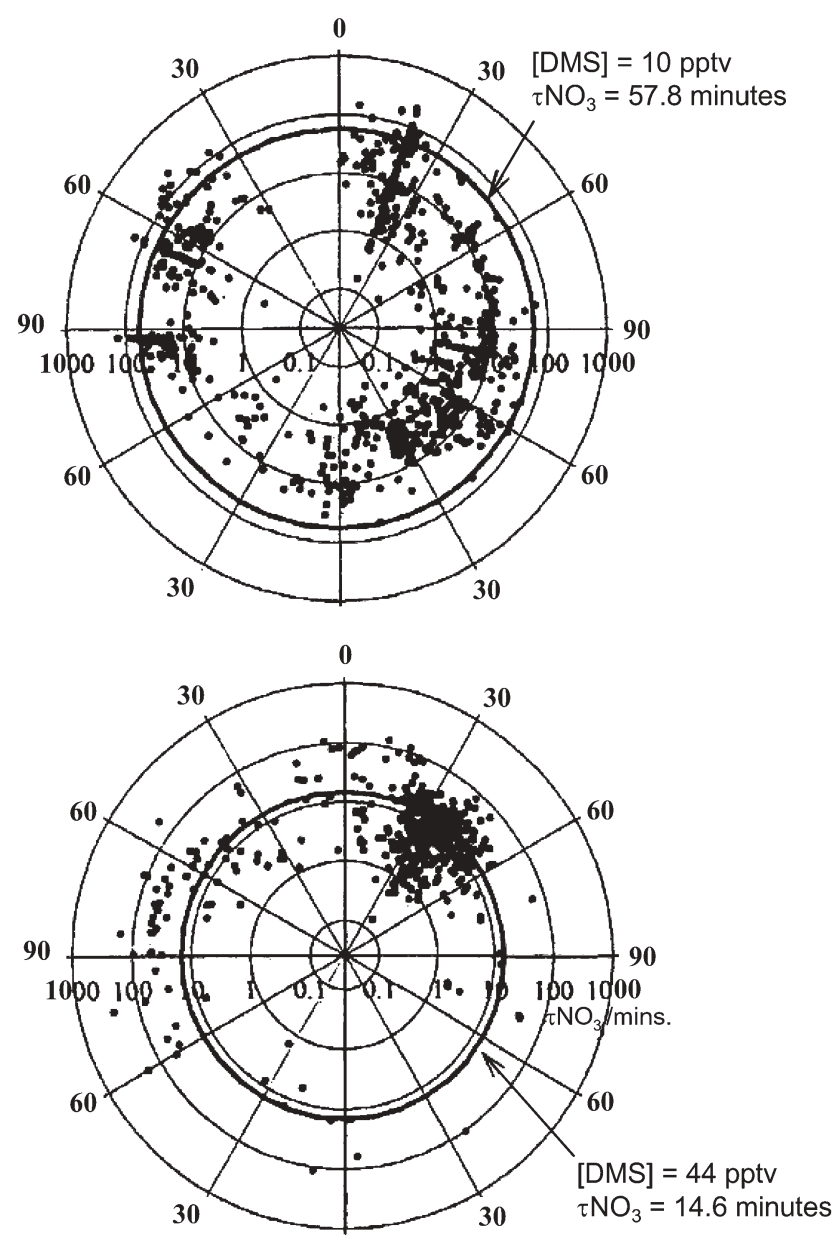

Fig. 16 Polar plots showing the observed lifetime of $\mathrm{NO}_{3}$ versus arrival wind direction for Mace Head, Ireland (top) and Tenerife (bottom) (after ref. 26). The black circle represents the calculated lifetime of $\mathrm{NO}_{3}$ from reaction with the campaign average [DMS] only.

and semi-polluted conditions. ${ }^{31,32}$ For example, Fig. 17 shows $\mathrm{NO}_{3} / \mathrm{RO}_{2}$ concentrations measured overnight at Weybourne on the North Norfolk coast of the UK. ${ }^{31}$ The $\mathrm{NO}_{3}$ and $\mathrm{RO}_{2}$ rise simultaneously at dusk and similarly decrease at sunrise. Under the conditions encountered at Weybourne, $\mathrm{NO}_{3}$ and $\mathrm{RO}_{2}$ concentrations are correlated, indicative of $\mathrm{NO}_{3}$ chemistry leading to night-time $\mathrm{HO}_{x}$ chemistry both from reactions with VOCs or through the involvement of $\mathrm{NO}_{3}$ in radical propagation. A simplified night-time VOC reaction scheme can be written where $\mathrm{NO}_{3}$ initiates the oxidation via the production of a precursor to the peroxy radical (46) and is also involved as a chain propagator via reaction (50)

$$
\begin{gathered}
\mathrm{NO}_{3}+\text { Organic Compound } \rightarrow \mathrm{R}+\text { products } \\
\mathrm{R}+\mathrm{O}_{2}+\mathrm{M} \rightarrow \mathrm{RO}_{2}+\mathrm{M} \\
\mathrm{RO}_{2}+\mathrm{NO}_{3} \rightarrow \mathrm{RO}+\mathrm{NO}_{2}+\mathrm{O}_{2} \\
\mathrm{RO}+\mathrm{O}_{2} \rightarrow \mathrm{R}^{\prime} \mathrm{R}^{\prime \prime} \mathrm{CO}+\mathrm{HO}_{2} \\
\mathrm{HO}_{2}+\mathrm{O}_{3} \rightarrow \mathrm{OH}+2 \mathrm{O}_{2} \\
\mathrm{HO}_{2}+\mathrm{NO}_{3} \rightarrow \mathrm{OH}+\mathrm{NO}+\mathrm{O}_{2}
\end{gathered}
$$


a)

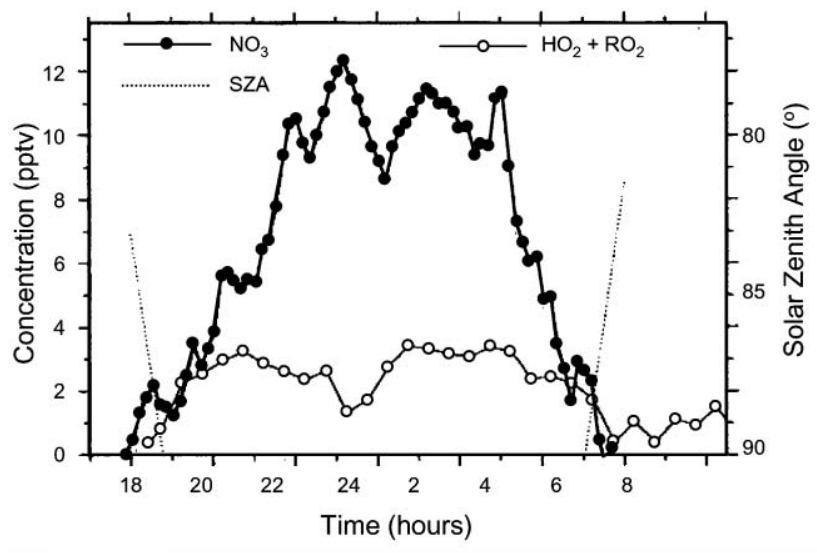

b)

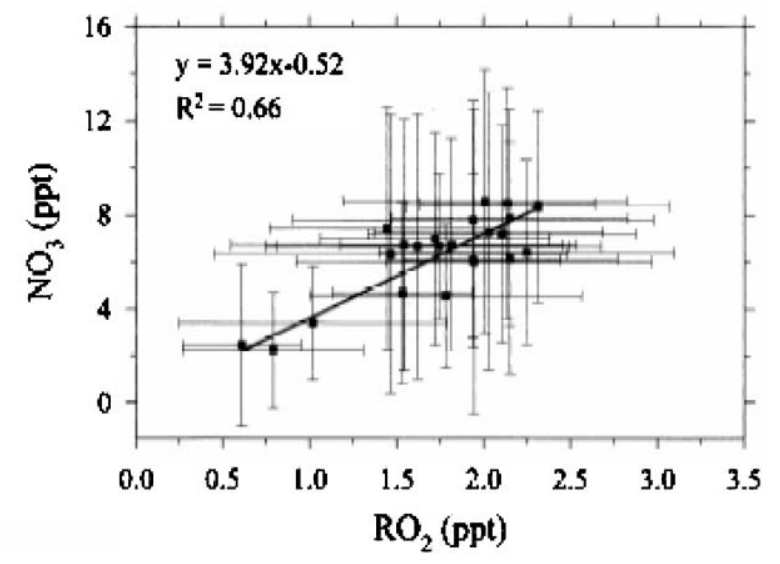

Fig. 17 a) Overnight concentrations of $\mathrm{NO}_{3}$ and $\mathrm{HO}_{2}+\mathrm{RO}_{2}$ as measured at the Weybourne Atmospheric Observatory on the North Norfolk Coast, UK on the 15th/16th April, 1994. The variation of the solar zenith angles indicates the times of sunset and sunrise (after ref. 31 ); b) Correlation plot for $\mathrm{NO}_{3}$ and $\mathrm{HO}_{2}+\mathrm{RO}_{2}$ for 5 nights of data from the same campaign. The error bars are the standard deviation of the averages and the range of concentrations of the observing period.

The generation of night-time $\mathrm{OH}$ can take place by the reaction of $\mathrm{HO}_{2}$ with ozone or $\mathrm{NO}_{3}$ (reactions 10 or 50). The eventual fate of the night-time $\mathrm{OH}$ is going to depend on a number of factors but in the simplest case it can react with $\mathrm{CO}$ and $\mathrm{CH}_{4}$ (reactions 6-9) to form peroxy radicals or react with $\mathrm{NO}_{2}$ to form $\mathrm{HNO}_{3}$ (reaction 19). It is worth noting that under different atmospheric conditions $\mathrm{NO}_{3}$ and $\mathrm{RO}_{2}$ are anticorrelated, indicative of the influence of fast-reacting organics in the night-time chemistry, or in some cases $\mathrm{NO}_{3}$ and $\mathrm{RO}_{2}$ are not correlated at all. ${ }^{33}$

Night-time oxidation chemistry may also be initiated by ozone-alkene chemistry (see Fig. 18) which, like $\mathrm{NO}_{3}$ chemistry, does not require light. Essentially the peroxy radical formed from the ozone-alkene chemistry (see Fig. 6) can follow the same reaction scheme as $\mathrm{NO}_{3}(47-50,15)$. It is worth noting here that $\mathrm{NO}_{3}$ acts as a chain carrier in night-time chemistry, since its reactions with peroxy radicals lead to night-time production of $\mathrm{OH}$. Kanaya et al. ${ }^{34}$ have observed ca. 3 pptv of $\mathrm{HO}_{2}$ at night at Oki Island, Japan, and suggested that ozone reactions with alkenes at night were more important for peroxy-radical production than $\mathrm{NO}_{3}$ reactions. a)

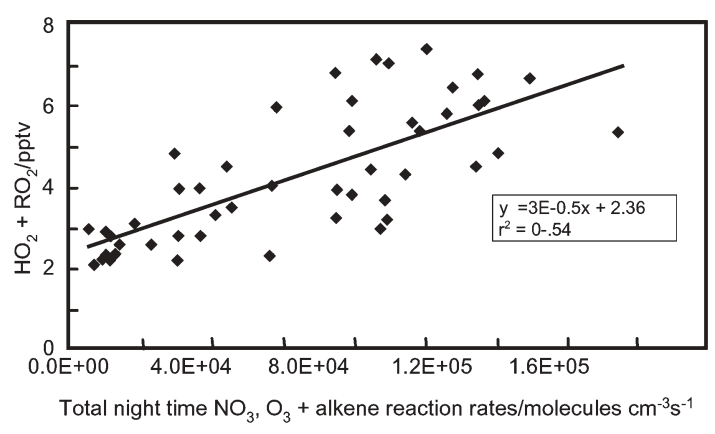

b)

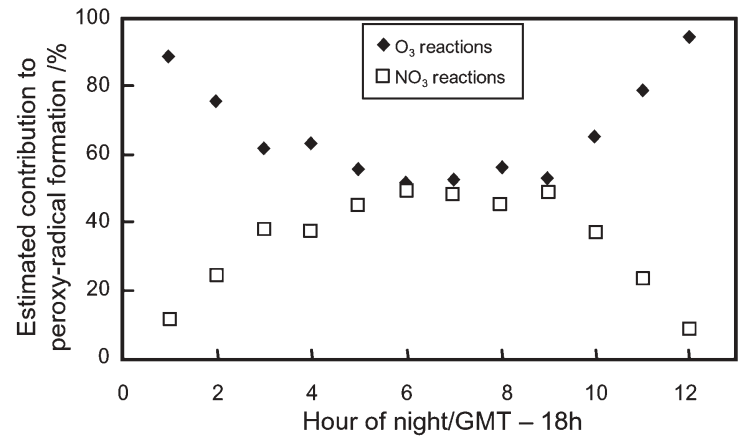

Fig. 18 a) Scatter plot of the total night-time rate through the $\mathrm{NO}_{3}$, $\mathrm{O}_{3}$ and alkene reactions versus $\left[\mathrm{HO}_{2}+\mathrm{RO}_{2}\right]$ for Mace Head, Ireland demonstrating the correlation between peroxy radical concentrations and night-time alkene oxidation. b) The estimated percentage contribution of $\mathrm{NO}_{3}$ reactions and $\mathrm{O}_{3}$ reactions to peroxy radical formation at night during the same campaign. ${ }^{33}$

Salisbury et al. ${ }^{33}$ have shown that in semi-polluted conditions the reaction between ozone and alkenes can be a more significant loss process for alkenes than the concomitant reactions with $\mathrm{NO}_{3}$. Indeed, the reaction of ozone with alkenes was the dominant source of peroxy radicals at night (see Fig. 18).

One recent result of note is that Geyer et $a l^{25}$ have demonstrated that under highly polluted conditions in Houston, Texas that $\mathrm{NO}_{3}$ can also be present during the daytime and significantly contribute to the oxidation of certain VOCs such as $\alpha$-pinene, $p$-cresol and other monoterpenes.

From the preceding discussion it has been seen that the involvement of $\mathrm{NO}_{3}$ chemistry in gas-phase tropospheric chemistry potentially has several significant consequences: ${ }^{27}$

a) The radical can control $\mathrm{NO}_{y}$ speciation in the atmosphere at night (via reaction 35).

b) Nitric acid can be formed, by hydrolysis of $\mathrm{N}_{2} \mathrm{O}_{5}$, as a product of a hydrogen abstraction process or indirectly via the $\mathrm{NO}_{3}$ mediated production of $\mathrm{OH}$, which can react with $\mathrm{NO}_{2}$ (reaction 19) to produce nitric acid.

c) Primary organic pollutants can be oxidised and removed at night.

d) Radicals $\left(\mathrm{HO}_{x}\right.$ and $\left.\mathrm{RO}_{2}\right)$ produced by $\mathrm{NO}_{3}$ chemistry can act as initiators for chain oxidation chemistry.

e) Toxic or otherwise noxious compounds such as peroxyacylnitrates, other nitrates and partially oxidised compounds may be formed.

f) Nitrate products or $\mathrm{NO}_{3}$ itself may act as temporary reservoirs in the presence of $\mathrm{NO}_{x}$. 
g) Under highly polluted conditions $\mathrm{NO}_{3}$ may be a significant daytime oxidant for certain compounds.

\section{Halogen radicals (XO, OXO)}

In comparison to the atmospheric chemistry taking place in the stratosphere where halogen chemistry is well known and characterised, there has been much debate as to the role of halogen species in the oxidative chemistry of the troposphere. ${ }^{35}$ There is growing experimental evidence as to the prevalence of halogen chemistry as part of tropospheric photochemistry (see Table 5). ${ }^{35}$ Much of the proposed halogen chemistry is propagated through the reactions of a series of halogen atoms and radicals.

Bromine oxide species can be formed in the polar boundary layer $^{36,37}$ and areas with high salt levels such as the Dead Sea. ${ }^{38}$ The major source of gas-phase bromine in the lower troposphere is thought to be the release of species such as $\mathrm{IBr}$, $\mathrm{ICl}, \mathrm{Br}_{2}$ and $\mathrm{BrCl}$ from sea-salt aerosol, following the uptake from the gas-phase and subsequent reactions of hypohalous acids $(\mathrm{HOX}$, where $\mathrm{X}=\mathrm{Br}, \mathrm{Cl}, \mathrm{I}){ }^{39}$ The halogen release mechanism is autocatalytic ${ }^{37}$ and has become known as the "Bromine explosion". A further release mechanism is the heterogeneous uptake of $\mathrm{N}_{2} \mathrm{O}_{5}$ (formed at night from $\mathrm{NO}_{3}$ chemistry, see earlier section), that can react with sea-salt bromide to release $\mathrm{BrONO}_{2} \cdot{ }^{40}$ The wide-spread occurrence of these heterogeneous mechanisms are supported by the observed depletion of bromide ions in sea-salt aerosol. ${ }^{41,42}$ The initiation of the $\mathrm{BrO}$ chemistry is relatively simple, viz.

$$
\begin{aligned}
& \mathrm{BrX}+h v \rightarrow \mathrm{Br}+\mathrm{X} \\
& \mathrm{Br}+\mathrm{O}_{3} \rightarrow \mathrm{BrO}+\mathrm{O}_{2}
\end{aligned}
$$

The major sources of iodine are thought to be from macroalgal sources releasing organoiodine compounds. ${ }^{43,44}$ Photolysis of the organoiodine compounds releases the iodine.

$$
\begin{aligned}
& \mathrm{RI}_{x}+h v \rightarrow \mathrm{R}+\mathrm{I} \\
& \mathrm{I}+\mathrm{O}_{3} \rightarrow \mathrm{IO}+\mathrm{O}_{2}
\end{aligned}
$$

During daylight hours iodine monoxide, IO exists in a fast photochemical equilibrium with I, viz.

$$
\mathrm{IO}+h v \rightarrow \mathrm{I}+\mathrm{O}
$$

The aerosol "explosion" mechanism, previously described for bromine, acts effectively to recycle the iodine back to the gas-phase. The situation with respect to chlorine source gases is less clear (see Experimental Evidence section).

In general, during the daylight hours halogen atoms can be recycled in a steady-state null cycle

$$
\begin{aligned}
& \mathrm{X}+\mathrm{O}_{3} \rightarrow \mathrm{XO}+\mathrm{O}_{2} \\
& \mathrm{XO}+h v \rightarrow \mathrm{X}+\mathrm{O} \\
& \mathrm{O}_{3}+h v \rightarrow \mathrm{O}_{2}+\mathrm{O}
\end{aligned}
$$

In more polluted regimes, the reaction of the halogen monoxide with NO may act to reform the halogen atom

$$
\mathrm{XO}+\mathrm{NO} \rightarrow \mathrm{X}+\mathrm{NO}_{2}
$$

as well as the appropriate self and cross reactions

$$
\begin{aligned}
\mathrm{XO}+ & \mathrm{YO} \rightarrow \mathrm{X}+\mathrm{Y}+\mathrm{O}_{2} \\
& \rightarrow \mathrm{XY}+\mathrm{O}_{2} \\
& \rightarrow \mathrm{OXO}+\mathrm{Y}
\end{aligned}
$$

The $[\mathrm{X}] /[\mathrm{XO}]$ ratio is largely determined by a combination of the reactions (56), (57), (59), (60). At any given time $<0.1 \%$ for $\mathrm{Cl}, 0.1$ to $1 \%$ for $\mathrm{Br}$ and several $10 \%$ for I will be present in the form of a halogen atom.

Halogen atoms are efficient oxidising species and can lead to the degradation of VOCs. Chlorine atoms are of particular interest because they are $10^{3}$ times more reactive than $\mathrm{OH}$ and therefore even at low concentrations have the ability to enhance hydrocarbon oxidation in the atmosphere via

$$
\mathrm{RH}+\mathrm{Cl} \rightarrow \mathrm{R}+\mathrm{HCl}
$$

An alternative fate of the halogen atom is the reaction with either formaldehyde (or higher aldehydes) or $\mathrm{HO}_{2}$, both of which lead to the formation (as with reaction (61)) of hydrogen halides

$$
\begin{gathered}
\mathrm{X}+\mathrm{HO}_{2} \rightarrow \mathrm{HX}+\mathrm{O}_{2} \\
\mathrm{X}+\mathrm{HCHO} \rightarrow \mathrm{HX}+\mathrm{CHO}
\end{gathered}
$$

Reaction (62) occurs for $\mathrm{X}=\mathrm{Cl}, \mathrm{Br}$ and $\mathrm{I}$, whereas reaction (63) does not occur for $\mathrm{X}=\mathrm{I}$. The fate of the hydrogen halides in the lower troposphere is irreversible loss by either dry or wet deposition owing to the highly water soluble nature of these

Table 5 Sources of reactive halogen species found in various parts of the troposphere (after ref. 35)

\begin{tabular}{ll}
\hline Species, site & Likely source mechanism \\
\hline $\mathrm{ClO}_{x}$ in the polar boundary layer & By-product of the "Bromine explosion", \\
$\mathrm{ClO}_{x}$ by salt flats & By-product of the "Bromine explosion" \\
$\mathrm{BrO}_{x}$ in the polar boundary layer & Autocatalytic release from sea-salt on ice, "Bromine explosion" mechanism \\
$\mathrm{BrO}_{x}$ in the Dead sea basin & "Bromine explosion" (salt pans) \\
$\mathrm{BrO}_{x}$ in the free troposphere & $(1)$ Photo-degradation of hydrogen containing organo-halogen species $\left(e . g . \mathrm{CH}_{3} B r\right)$, \\
$\mathrm{BrO}_{x}$ in the marine boundary layer & $(2)$ "Spill-out" from the boundary layer, (3) Transport from the stratosphere? \\
$\mathrm{IO}_{x}$ in the marine boundary layer & "Bromine explosion" mechanism
\end{tabular}


class of compounds. In drier regions of the atmosphere it is possible to cycle the hydrogen halide to the $\mathrm{X} / \mathrm{XO}$ species via

$$
\mathrm{OH}+\mathrm{HX} \rightarrow \mathrm{X}+\mathrm{H}_{2} \mathrm{O}
$$

A simplified scheme for the inorganic halogen chemistry described is given in Fig. 19. There are two other important classes of halogen reservoir compounds beyond HX namely, $\mathrm{HOX}$ and $\mathrm{XONO}_{2}$. HOX compounds are formed from the reaction of $\mathrm{XO}$ with the hydroperoxy radical

$$
\mathrm{XO}+\mathrm{HO}_{2} \rightarrow \mathrm{HOX}+\mathrm{O}_{2}
$$

This is rapidly followed by photolysis

$$
\mathrm{HOX}+h v \rightarrow \mathrm{X}+\mathrm{OH}
$$

In the sunlit atmosphere a photostationary state is established with $[\mathrm{HOX}] /[\mathrm{XO}]$ ranging from 1 to 10 . As previously indicated $\mathrm{HOBr}$, the hypohalous acid of $\mathrm{Br}$, is implicated in the bromine explosion mechanism ${ }^{37,39}$

$$
\mathrm{HOBr}+\left(\mathrm{Br}^{-}\right)_{\mathrm{aq}}+\mathrm{H}^{+} \rightarrow \mathrm{Br}_{2}+\mathrm{H}_{2} \mathrm{O}
$$

The $\mathrm{Br}_{2}$ produced in reaction (67) is rapidly photolysed, producing bromine atoms that can be oxidised to $\mathrm{BrO}$ by $\mathrm{O}_{3}$ (reaction (56)), the resultant $\mathrm{BrO}$ reacting with $\mathrm{HO}_{2}$ (reaction 65) (or $\mathrm{CH}_{3} \mathrm{O}_{2}$ ) to reform $\mathrm{HOBr}$. Thus, the complete cycle has the form

$$
\mathrm{BrO}+\mathrm{O}_{3}+\left(\mathrm{Br}^{-}\right)_{\mathrm{aq}}+\left(\mathrm{H}^{+}\right)_{\mathrm{aq}} \stackrel{\text { surface, } \mathrm{HO} x}{\longrightarrow} 2 \mathrm{BrO}+\text { products }
$$

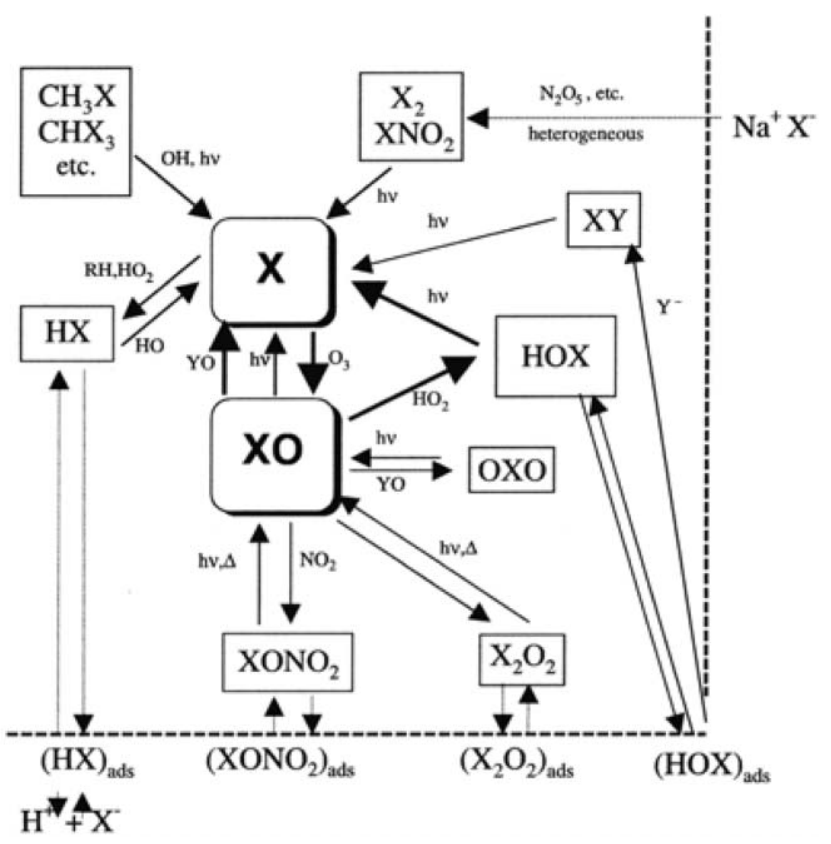

Fig. 19 Simplified scheme of the inorganic halogen reactions in the boundary layer $(\mathrm{X}=\mathrm{Cl}, \mathrm{Br}, \mathrm{I}){ }^{35}$ The reactive halogen sources are release from sea salt or photochemical degradation of organohalogen species. where effectively one $\mathrm{BrO}$ molecule is converted to two by oxidation of bromide from a suitable surface. Fig. 20 shows a schematic representation of the bromine explosion mechanism. $^{45,46}$ It is worth noting that the bromine explosion mechanism only occurs from sea salt with a $\mathrm{pH}<6.5$ therefore requiring acidification of the aerosol potentially caused by the uptake of strong acids likely to be of anthropogenic origins or naturally occurring acids. ${ }^{41,42}$

There are other mechanisms for the photochemical release of $\mathrm{Br}_{2}$ from aqueous salt solutions. For example, it has been observed $^{47}$ that there is a photochemical process whereby $\mathrm{HO}_{2}$ radicals can oxidize $\mathrm{Br}_{2}{ }^{-}$radical anions in aqueous salt solutions via a $\mathrm{pH}$ dependent mechanism to produce $\mathrm{Br}_{2}$. Another potential mechanism is $\mathrm{OH}$ radical oxidation of aqueous bromide. $^{48}$

Another class of XO reservoir species are the halogen nitrates formed by the reaction

$$
\mathrm{XO}+\mathrm{NO}_{2} \stackrel{\mathrm{M}}{\longleftrightarrow} \mathrm{XONO}_{2}
$$

For example, $\mathrm{BrONO}_{2}$ is quite thermally stable, but readily photolysed and may be converted to HOX by heterogeneous hydrolysis or to $\mathrm{Br}_{2}$ and $\mathrm{BrCl}$ by heterogeneous reaction with HY. It is unlikely that $\mathrm{XONO}_{2}$ is of major importance in the free troposphere where ambient $\left[\mathrm{NO}_{x}\right]$ is low but may be important in more polluted areas.

Potentially, the most important effect of reactive halogen species maybe that their chemistry may lead to the catalytic destruction of ozone via two distinct cycles

Cycle I:

$$
\begin{gathered}
\mathrm{XO}+\mathrm{YO} \rightarrow \mathrm{X}+\mathrm{Y}+\mathrm{O}_{2}\left(\text { or } \mathrm{XY}+\mathrm{O}_{2}\right) \\
\mathrm{X}+\mathrm{O}_{3} \rightarrow \mathrm{XO}+\mathrm{O}_{2} \\
\mathrm{Net}: \mathrm{O}_{3}+\mathrm{O}_{3} \rightarrow 3 \mathrm{O}_{2}
\end{gathered}
$$

\section{The Bromine explosion}

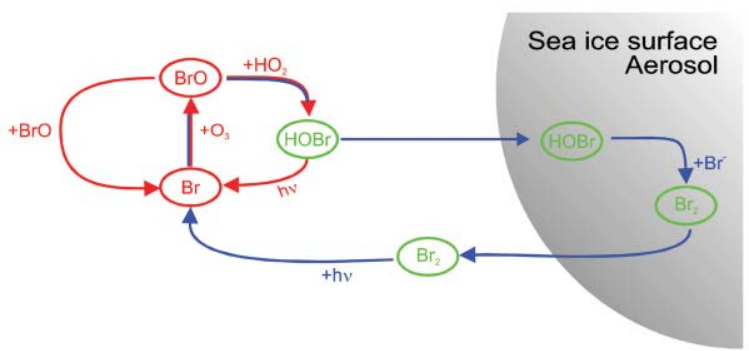

\begin{tabular}{|lr|}
\hline $\begin{array}{l}\text { Heterogeneous release of bromine } \\
\text { on sea salt surfaces }\end{array}$ & $\begin{array}{c}\mathrm{BrO}+\mathrm{HO}_{2} \rightarrow \mathrm{HOBr}+\mathrm{O}_{2} \\
\mathrm{HOBr}(g)+\mathrm{Br}^{-}(a q)+\mathrm{H}^{+} \rightarrow \mathrm{Br}_{2}(g)+\mathrm{H}_{2} \mathrm{O}\end{array}$ \\
\hline Catalytical ozone destruction & $2 \mathrm{O}_{3} \stackrel{\mathrm{Br}, \mathrm{BrO}}{\longrightarrow} 3 \mathrm{O}_{2}$ \\
\hline
\end{tabular}

Fig. 20 A schematic representation of the so-called bromine explosion mechanism where effectively one $\mathrm{BrO}$ molecule is converted to two by oxidation of bromide from a suitable aerosol surface. ${ }^{64}$ 
In cycle I, the rate limiting step involves reaction (60), the self- or cross- reaction of the halogen monoxide radicals. Typically, channels of the self-reaction (60c) leading to the formation of OXO do not contribute to ozone loss with the exception of OIO which is thought to have a photodissociative channel that forms iodine atoms. ${ }^{49}$ Cycle I has been identified to be the prime cause for polar boundary layer ozone destruction. ${ }^{36}$ The second ozone destruction cycle, which is more prevalent at low halogen levels, has the form

Cycle II:

$$
\begin{gathered}
\mathrm{XO}+\mathrm{HO}_{2} \rightarrow \mathrm{HOX}+\mathrm{O}_{2} \\
\mathrm{HOX}+h v \rightarrow \mathrm{X}+\mathrm{OH} \\
\mathrm{X}+\mathrm{O}_{3} \rightarrow \mathrm{XO}+\mathrm{O}_{2} \\
\mathrm{OH}+\mathrm{CO} \rightarrow \mathrm{H}+\mathrm{CO}_{2}(+\mathrm{M}) \rightarrow \mathrm{HO}_{2} \\
\mathrm{Net}: \mathrm{O}_{3}+\mathrm{CO}+h v \rightarrow \mathrm{CO}_{2}+\mathrm{O}_{2}
\end{gathered}
$$

The rate determining step in this reaction sequence is reaction (65) making ozone destruction linearly dependent on [XO]. The fraction of HOX that photolyses to give back $\mathrm{OH}$ depends critically on the accommodation coefficient of HOX on aerosols. Currently, there is a large uncertainty in this parameter. An important side-effect of cycle II is the potential for the reduction of the $\left[\mathrm{HO}_{2}\right] /[\mathrm{OH}]$ ratio by consumption of $\mathrm{HO}_{2}$. The inorganic halogen chemistry described is summarised in Fig. 19.

An example of the potential effect of the ozone depletion cycles (cycles I and II) can be found using data from the marine boundary layer. ${ }^{50}$ Table 6 lists the rates of ozone depletion (from cycles I and II) in the first hour after sunrise at Mace Head in Ireland. Measurements of [BrO] show a pulse in the first two hours after dawn ascribed to the photolysis of inorganic bromine compounds produced either by the bromine explosion mechanism ${ }^{39}$ or the photolysis of mixed bromo/ iodo-organohalogens ${ }^{43}$ built up overnight. Using measured concentrations of $\mathrm{BrO}, \mathrm{IO}$ and $\mathrm{HO}_{2}$ the data in Table 6 shows the ozone depletion cycle (cycle type I) involving the $\mathrm{BrO}$ and
Table 6 Rates of ozone depletion by various catalytic cycles involving XO using measured data typical of marine boundary layer just after sunrise (after ref. 50)

\begin{tabular}{lll}
\hline $\begin{array}{l}\text { Rate determining } \\
\text { reaction }\end{array}$ & $\begin{array}{l}\text { Cycle } \\
\text { (see text) }\end{array}$ & $\begin{array}{l}\mathrm{O}_{3} \text { removal } \\
\text { rate } / \mathrm{ppbv} \mathrm{h}^{-1}\end{array}$ \\
\hline $\mathrm{BrO}+\mathrm{IO}$ & $\mathrm{I}$ & 0.13 \\
$\mathrm{IO}+\mathrm{HO}_{2}$ & $\mathrm{II}$ & 0.08 \\
$\mathrm{IO}+\mathrm{IO}$ & $\mathrm{I}$ & 0.06 \\
$\mathrm{BrO}+\mathrm{HO}_{2}$ & II & 0.03 \\
$\mathrm{BrO}+\mathrm{BrO}$ & $\mathrm{I}$ & 0.01 \\
${ }^{a} \mathrm{All}$ rates calculated at & $T=295 \mathrm{~K}$ for $\mathrm{BrO}=3$ pptv, IO $=2$ pptv \\
and $\mathrm{HO}_{2}=3$ pptv. & \\
\hline
\end{tabular}

IO cross-reaction is the most important with an $\mathrm{O}_{3}$ depletion rate of $0.3 \mathrm{ppbv}^{-1}$. This post-sunrise ozone depletion fits with speculation by Galbally et $a l^{51}$ who observed a postsunrise dip in the ozone diurnal cycle with an ozone loss rate of $0.1-0.4 \mathrm{ppb} \mathrm{h}^{-1}$ in the remote marine boundary layer and ascribed the observation to halogen chemistry.

\section{Experimental evidence}

By far the most prevalent halogen radical species, even observable from space, is $\mathrm{BrO}^{52}$ (see Fig. 21). In the spring time in both the Arctic and Antarctic large clouds of $\mathrm{BrO}$ enriched air masses are observable from space. These clouds cover several thousand square kilometres over the polar sea ice with $\mathrm{BrO}$ levels up to $30 \mathrm{pptv}$. The $\mathrm{BrO}$ is always coincident with low levels of ozone in the marine boundary layer. ${ }^{53}$ In order to observe these events there is a requirement for meteorological conditions that stop mixing between the boundary layer and the free troposphere and sunlight to drive the required photolysis of gaseous bromine (see reaction (67)) released heterogeneously through chemical processes on the ice. Because of the prerequisites for strong surface inversions to confine the air and sunlight, episodes of bromine explosion events and boundary layer ozone depletion tend to be confined to spring. It is thought that frost flowers in the Antarctic, which are formed on a liquid layer with high salinity on top of the sea ice surface, are likely to provide a large surface area for the heterogeneous release of reactive bromine. ${ }^{55}$ Fig. 22 shows
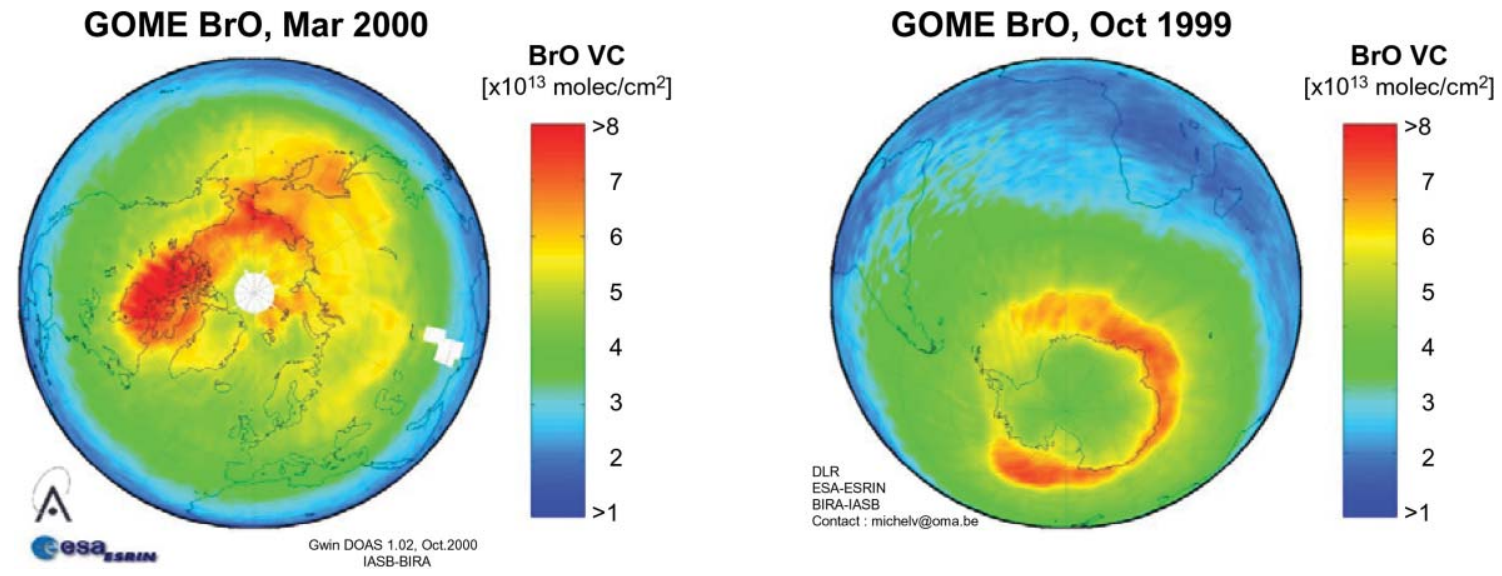

Fig. $21[\mathrm{BrO}]$ in the Antarctic and Artic during spring derived from GOME satellite measurements. ${ }^{65}$ 
a time series of measured $\mathrm{BrO}, \mathrm{O}_{3}$, sea ice contact and light path enhancement made from an Antarctic research station near the sea ice boundary. ${ }^{53}$ The measurements illustrate the $\mathrm{BrO} / \mathrm{O}_{3}$ anti-correlation in periods where air masses arrive with long sea ice contact times. It is noticeable that most of the enhanced periods of $\mathrm{BrO}$ also coincide with enhanced light paths, this is indicative of the increased aerosol arriving from the sea. Away from polar regions and those with high salt levels ${ }^{38}$ there is growing evidence from aerosol measurements of the widespread prevalence of the bromine explosion mechanism over oceanic areas. ${ }^{42}$

Beyond boundary layer $\mathrm{BrO}$ production from the explosion mechanism, there is growing evidence that $\mathrm{BrO}$ may pervade throughout the free troposphere at the $0.6-2 \mathrm{pptv}$ level $\mathrm{l}^{52,55}$ having implications for the global oxidation capacity. As part of Antarctic studies ${ }^{53}$ advection processes have been found to lift spring time $\mathrm{BrO}$ (see Fig. 21) into the free troposphere providing one possible source (see Table 5).

Fig. 23 shows the measured concentration of iodine monoxide (IO) at Mace Head in Ireland. ${ }^{56}$ The data in Fig. 23 show not only a clear requirement for radiation for photochemical production of IO but also a strong correlation with low tide conditions. The correlation with low tidal conditions is indicative of the likely sources of $\mathrm{IO}$, in that the photolysis of organoiodine compounds (reaction (53)) such as $\mathrm{CH}_{2} \mathrm{I}_{2}$ and $\mathrm{CH}_{2} \mathrm{IBr}$ emitted from macroalgae in the intertidal zone are possibly the candidate iodine sources. The photolysis lifetime of a molecule such as diodomethane is only a few minutes at midday. There is some indication that $\mathrm{CH}_{2} \mathrm{I}_{2}$ may come from an offshore as well as an intertidal source. ${ }^{56}$ Recent experimental observations have suggested the $I_{2}$ can be emitted directly from the macroalgae at low tide making this a substantial source of iodine. ${ }^{57}$ Modelling of $\mathrm{IO}$ observations $^{58}$ with concentrations up to 4 pptv (cf. Fig. 23) has shown that the iodine catalysed destruction of ozone was

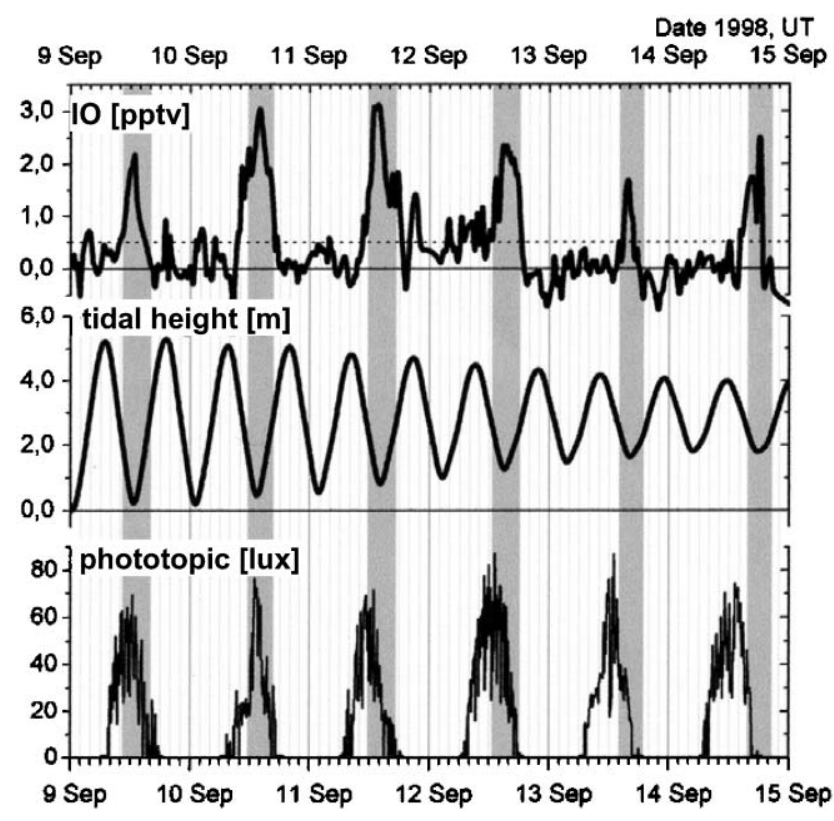

Fig. 23 [IO], tidal height and solar radiation measured at Mace Head in Ireland. ${ }^{56}$ The grey areas represent the low tide areas during the day. The dotted line in the upper panel is the IO detection limit.

of a similar magnitude to that driven by $\mathrm{HO}_{x}$ photochemistry, with up to $13 \%$ of the available ozone destroyed per day in marine air. The chemistry can also lead to an enrichment of iodine in the aerosol in the form of iodate this can provide a route to move biogenic iodine from ocean to land. ${ }^{56} \mathrm{~A}$ side effect of the iodine chemistry was denoxificaiton via the aerosol uptake of $\mathrm{IONO}_{2}$ formed from reaction (69).

There has been little direct evidence for chlorine chemistry; much has been inferred from so-called chemical-clock

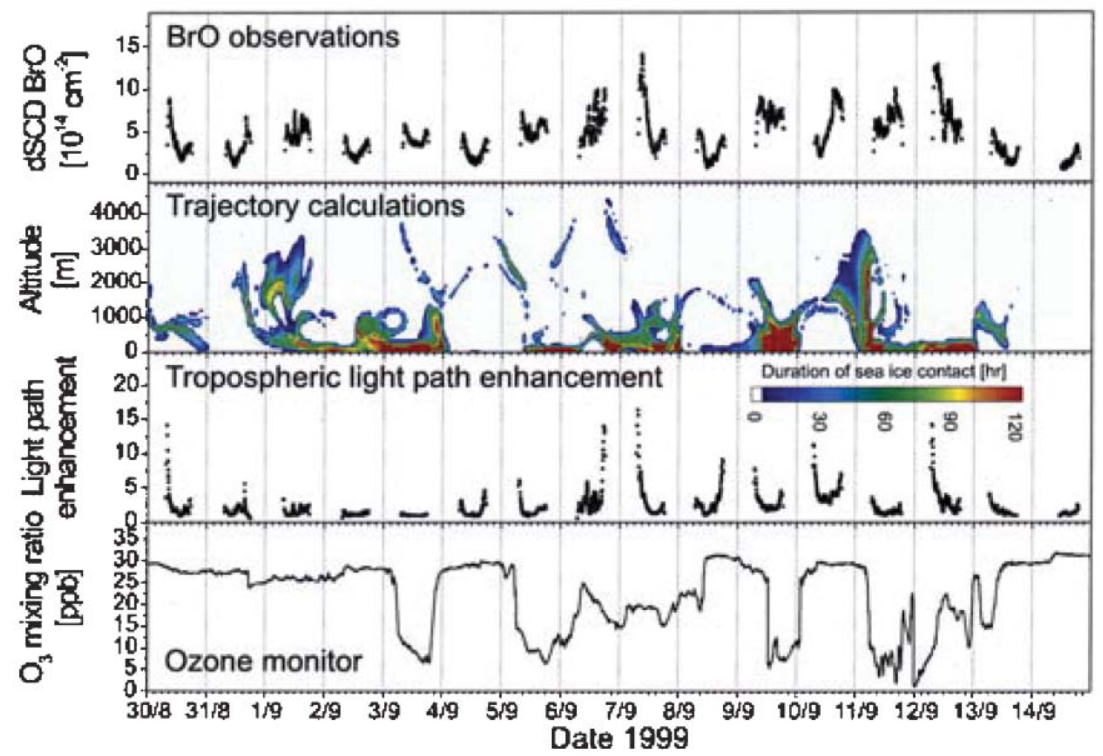

Fig. 22 Observations of enhanced $\mathrm{BrO}$ at an Antarctic research station (Neumayer, $70^{\circ} \mathrm{S}$ ). The other panels detail the corresponding sea ice contact time, light path enhancement factor (a proxy for aerosol) and surface ozone mixing ratio. ${ }^{53}$ 
experiments, where the differential loss rates of a range of NMHCs are used to elucidate the relative loss with respect to reaction with $\mathrm{OH}$ and $\mathrm{Cl}^{59}$ and therefore infer a $\mathrm{Cl}$ atom concentration. This form of study has inferred $\mathrm{Cl}$ atom concentrations in the vicinity of $10^{3}-10^{5}$ atom $\mathrm{cm}^{-3}$ in the marine boundary layer. On the other hand, $\mathrm{ClO}$ has been detected at a concentration of up to $15 \mathrm{pptv}$ in the area of Great Salt Lake in Utah (see Fig. 24). ${ }^{60}$ The authors speculate that the chlorine has been mobilised by heterogeneous reactions from the high molality salt solutions or crystalline salt on the flats, this likely to be the by-product of the bromine explosion mechanism (cf. reaction (67))

$$
\mathrm{HOBr}+\left(\mathrm{Cl}^{-}\right)_{\mathrm{aq}}+\mathrm{H}^{+} \rightarrow \mathrm{BrCl}+\mathrm{H}_{2} \mathrm{O}
$$

In order to maintain the observed level of $\mathrm{ClO}$ concentrations, in the order of $10^{5} \mathrm{Cl}$ atoms $\mathrm{cm}^{-3}$ is required. These levels of $\mathrm{Cl}$ have the potential to double the atmospheric oxidation capacity via the oxidation of hydrocarbons (reaction (61)). ${ }^{60}$

In summary, halogen radical chemistry can have a number of potential impacts on the chemistry of the troposphere:

a) Reactive bromine and iodine can destroy tropospheric ozone [e.g. ref 50].

b) The $\mathrm{HO}_{2}$ to $\mathrm{OH}$ ratio can be changed via reactions 65 and 66.

c) The NO to $\mathrm{NO}_{2}$ ratios can be altered via reaction 59 .

d) By a combination of b) and c) reactive halogen chemistry can limit photochemical ozone production in the free troposphere.

e) Bromine catalysed chlorine activation has the potential to enhance the tropospheric oxidation capacity. ${ }^{60}$

f) Reactive bromine could be responsible for upper tropospheric ozone loss. ${ }^{54}$

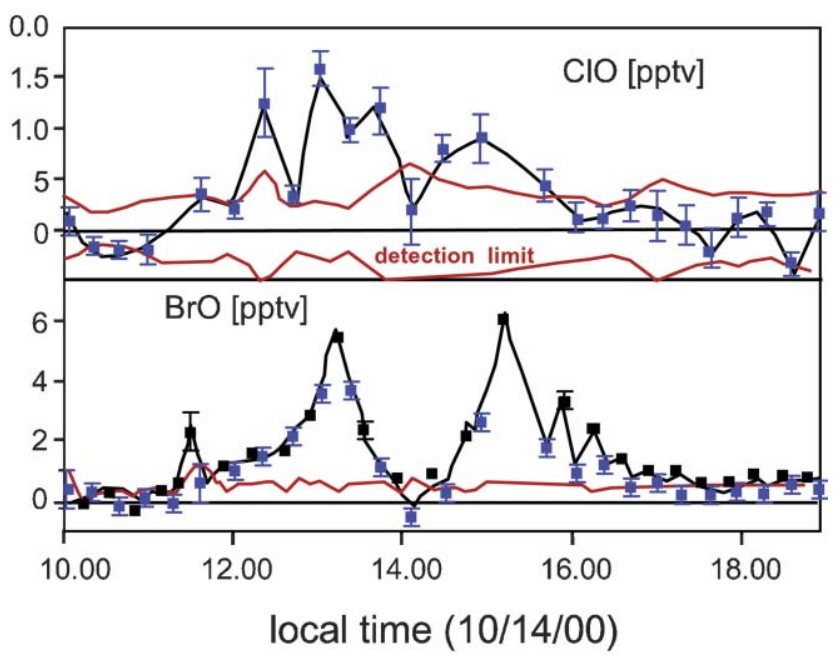

Fig. $24 \mathrm{ClO}, \mathrm{BrO}, \mathrm{NO}_{2}$ and $\mathrm{O}_{3}$ measurements adjacent to the Great Salt Lake in Utah, USA. The observations are the first direct measurement of $\mathrm{ClO}$ in the atmosphere. ${ }^{59}$ The solid brown lines show the detection limit from each individual spectrum; the lower (negative) brown line uses a different instrument set-up as a test for $\mathrm{ClO}$ sensitivity (see ref. 59 details). All errors are at $1 \sigma$. g) The deposition rate of $\mathrm{Hg}$ may be enhanced by the presence of bromine species. ${ }^{61}$

h) $\mathrm{BrO}$ may act as a sink for DMS in unpolluted marine environments.

i) Iodine species might be involved in particle formation in the marine boundary layer.

There are a number of key observational led questions that are required to be answered in order to assess how widespread tropospheric halogen chemistry is, as well as the detailed chemistry and its impact.

\section{Summary}

In many ways, radicals remain the ghosts of atmospheric chemistry. The atmospheric free radicals are low concentration, relatively fast reacting species whose influence is felt throughout the atmosphere. In the changing atmosphere, where human-induced emissions are changing the trace gas composition, the reactive radicals have a key role to play in maintaining a balanced atmospheric composition through their central role in controlling the oxidative capacity of the atmosphere. In this review, the basic chemistry of three major classes of tropospheric radicals has been outlined. What is noticeable from an overview of the radical reactions is the interwoven nature of the chemistry. The fate of many radicals being dependent on species either produced or controlled by other radicals. In many respects this reflects the fascination of measuring and modelling radical chemistry, trying to unpick the interwoven garment of atmospheric chemistry.

There are still a number of outstanding issues in relation to radical chemistry. In the future we will need to understand climate-chemistry and chemistry-climate feedbacks and the effect on radical chemistry. In the changing climate, how will temperature, water availability, changing land-use/ emissions, cloudiness and many other climatically effected processes impact on the radical chemistry? Will changing radical concentrations have positive or negative feedbacks on the atmospheric lifetime of reactive greenhouse gases?

Further, there is the whole question of chemical complexity and radical chemistry. In the main this review has dealt with the relatively simple organic radicals, but there are a multitude of potential organic reactants that are capable of being oxidised by numerous chemical pathways with complex organic radical chemistry. The question arises what do we need to measure and understand in terms of radicals and trace species in the atmospheric context, to follow the complex organic chemistry? It must also be recognised that the atmosphere is a multi-phase environment in which we do not understand, as illustrated with some of the halogen chemistry, what the impact of heterogeneous processes are with respect to atmospheric radical chemistry. One thing is clear, there is still much to discover and understand about atmospheric radical chemistry and its effects.

\section{Acknowledgements}

The author would like to thank Dr. Tony Cox for useful discussions on tropospheric halogen chemistry. 
Paul S. Monks

Department of Chemistry, University of Leicester, Leicester,

UK LE1 7RH. E-mail: P.S.Monks@le.ac.uk

\section{References}

1 B. Weinstock and H. Niki, Nature, 1972, 176, 290-292.

2 H. Levy, Science, 1971, 173, 141-143.

3 D. E. Heard and M. J. Pilling, Chem. Rev, 2003, 103, 51635198.

4 G. Salisbury, P. S. Monks, S. Bauguitte, B. J. Bandy and S. A. Penkett, J. Atmos. Chem., 2002, 41, 163-187.

5 J. Leliveld, F. J. Dentener, W. Peters and M. C. Krol, Atmos. Chem. Phys. Discuss., 2004, 4, 3699-3720.

6 H. B. Singh, M. Kanakidou, P. J. Crutzen and D. J. Jacob, Nature, 1995, 378, 50-56.

7 G. Lammel and J. N. Cape, Chem. Soc. Rev., 1996, 25, 361-369.

8 R. Criegee, Angew. Chem., Int. Ed. Engl., 1975, 14, 745-752.

9 J. G. Calvert, R. Atkinson, J. A. Kerr, S. Madronich, G. K. Moortgat, T. J. Wallington and G. Yarwood, The mechanisms of atmospheric oxidation of the alkenes, Oxford University Press, Oxford, 2000.

10 S. E. Paulson, M. Y. Chung and A. S. Hasson, J. Phys. Chem. A, 1999, 103, 8125-8138.

11 D. Ehhalt, Phys. Chem. Chem. Phys., 1999, 24, 5401-5408.

12 P. Zanis, P. S. Monks, E. Schuepbach and S. A. Penkett, J. Atmos. Chem., 2000, 37, 1-27.

13 F. Holland, A. Hofzumahaus, J. Schäfer, A. Kraus and H.-W. Pätz, J. Geophys. Res., 2003, 108, 8246.

14 J. Lelieveld and P. J. Crutzen, Nature, 1990, 343, 227-233.

15 A. Volz, H. Geiss, S. McKeen and D. Kley, Correlation of ozone and solar radiation at Montsouris and Hohenpeissenberg: Indications for photochemical influence, in Tropospheric Ozone, Prod. Quadr. Ozone Symp., Göttingen 1987, Deepak Publ., 447-450 (eds. Bojkov and Fabian), 1989.

16 S. Sillman, Atmos. Environ., 1999, 33, 1821-1845.

17 G. P. Ayers, S. A. Penkett, R. W. Gillett, B. J. Bandy, I. E. Galbally, C. P. Meyer, C. M. Elsworth, S. T. Bentley and B. W. Forgan, Nature, 1992, 360, 446-448.

18 P. S. Monks, G. Salisbury, G. Holland, S. A. Penkett and G. P. Ayers, Atmos. Environ., 2000, 34, 2547-2561.

19 P. S. Monks, Atmos. Environ., 2000, 34, 3545-3561.

20 E. L. Atlas, B. A. Ridley and C. A. Cantrell, J. Geophys. Res., 2003, 103, 8353.

21 C. A. Cantrell, L. Maudlin, M. Zondlo, F. Eisele, E. Kosciuch, R. Shetter, B. Lefer, S. Hall, T. Campos, B. Ridley, J. Walega, A. Fried, B. Wert, F. Flocke, A. Weinheimer, J. Hannigan, M. Coffey, E. Atlas, S. Stepehens, B. Heikes, J. Snow, D. Blake, N. Blake, A. Katzenstein, J. Lopez, E. V. Browell, J. Dibb, E. Scheuer, G. Seid and R. Talbot, J. Geophys. Res., 2003, 108, 8361.

22 L. Jaeglé, D. J. Jacob, W. H. Brune, I. C. Faloona, D. Tan, Y. Kondo, G. W. Sasche, B. Anderson, G. L. Gregory, S. Vay, H. B. Singh, D. R. Blake and R. Shetter, Geophys. Res. Lett., 1999, 26, 3081-3084.

23 S. R. Arnold, M. P. Chipperfield, M. A. Blitz, D. E. Heard and M. J. Pilling, Geophys. Res. Lett., 2004, 31, L07110.

24 M. Claeys, B. Graham, G. Vas, W. Wang, R. Vermeylen, V. Pashynska, J. Cafmeyer, P. Guyon, M. O. Andreae, P. Artaxo and W. Maenhaut, Science, 2004, 303, 1173-1176.

25 A. Geyer, R. Ackerman, M. Martinez, H. Harder, W. Brune, P. diCarlo, E. Williams, T. Jobson, S. Hall, R. Shetter and J. Stutz, J. Geophys. Res. (Atmos.), 2003, 108, 4368.

26 B. J. Allan, N. Carslaw, H. Coe, R. A. Burgess and J. M. C. Plane, J. Atmos. Chem., 1999, 33, 129-154; B. J. Allan, G. McFiggans, J. M. C. Plane, H. Coe and G. G. McFadyen, J. Geophys. Res., 2000, 105, 24191-24204.

27 R. P. Wayne, I. Barnes, P. Biggs, J. P. Burrows, C. E. Canosa-Mas, J. Hjorth, G. LeBras, G. K. Moortgat, D. Perner, G. Poulet, G. Restelli and H. Sidebottom, Atmos. Environ., 1991, 25, $1-203$.

28 R. P. Wayne, Chemistry of Atmospheres, 3rd ed., Oxford University Press, Oxford, UK, 2000.

29 U. Platt, D. Perner, A. M. Winer, G. W. Harris and J. N. Pitts, jr., Geophys. Res. Lett., 1980, 7, 11965-11970.
30 J. F. Noxon, R. B. Norton and E. Marovich, Geophys. Res. Lett., 1980, 7, 125-128.

31 N. Carslaw, L. J. Carpenter, J. M. C. Plane, B. J. Allan, R. A. Burgess, K. C. Clemitshaw, H. Coe and S. A. Penkett, J. Geophys. Res.(Atmos.), 1997, 102, 18917-18933.

32 A. Geyer, K. Bachmann, A. Hofzumahaus, F. Holland, S. Konrad, T. Klupfel, H. W. Patz, D. Perner, D. Mihelcic, H. J. Schafer, A. Volz-Thomas and U. Platt, J. Geophys. Res. (Atmos.), 2003, 108, 8249 .

33 G. Salisbury, A. R. Rickard, P. S. Monks, B. J. Allan, S. Bauguitte, S. A. Penkett, N. Carslaw, A. C. Lewis, D. J. Creasey, D. E. Heard, P. J. Jacobs and J. D. Lee, J. Geophys. Res. (Atmos.), 2001, 106, 12,669-12,688.

34 Y. Kanaya, Y. Sadanaga, J. Matsumoto, U. K. Sharma, J. Hirokawa, Y. Kajii and H. Akimoto, Geophys. Res. Lett., 1999, 26, 2179-2182.

35 U. Platt and G. Honniger, Chemosphere, 2003, 52, 325-338.

36 L. A. Barrie, J. W. Bottenheim, R. C. Schnell, P. J. Crutzen and R. A. Rasmussen, Nature, 1988, 334, 138-141.

37 S. M. Fan and D. J. Jacob, Nature, 1992, 359, 522-524.

38 K. Heibestreit, J. Stutz, D. Rosen, V. Matveiv, M. Peleg, M. Luria and U. Platt, Science, 1990, 283, 55-57.

39 R. Vogt, P. J. Crutzen and R. Sander, Nature, 1996, 383, $327-$ 330.

40 B. J. Finlayson-Pitts and S. N. Johnson, Atmos. Environ., 1988, 22, 1107-1112.

41 G. P. Ayers, R. W. Gillett, J. M. Cainey and A. L. Dick, J. Atmos.Chem., 1999, 33, 299-319.

42 R. Sander, W. C. Keene, A. A. P. Pzszenny, R. Arimoto, G. P. Ayers, E. Baboukas, J. M. Cainey, P. J. Crutzen, R. A. Duce, G. Hönninger, B. J. Huebert, W. Maenhaut, N. Mihalopoulos, V. C. Turekian and R. Van Dingenen, Atmos. Chem. Phys., 2003, 3, 1301-1336.

43 L. J. Carpenter, W. T. Sturges, S. A. Penkett, P. S. Liss, B. Alicke, K. Hebestreit and U. Platt, J. Geophys. Res., 1999, 104, 16791689.

44 L. J. Carpenter, Chem. Rev., 2003, 103, 4953-4962.

45 U. Platt and C. Janssen, Faraday Discuss, 1996, 100, 175-198.

46 P. O. Wennberg, Nature, 1999, 397, 299-301.

47 B. M. Mathew, I. George and C. Anastasio, Geophys. Res. Lett., 2003, 30, 2297.

48 M. Mozurkewich, J. Geophys. Res., 1995, 100, 14,199-14,208.

49 S. H. Ashworth, B. J. Allan and J. M. C. Plane, Geophys. Res. Lett., 2002, 29, 1456.

50 A. Saiz-Lopez, J. M. C. Plane and J. A. Shillito, Geophys. Res. Lett., 2004, 31, L03111.

51 I. E. Galbally, S. T. Bentley and C. P. Meyer, Geophys. Res. Lett., 2000, 27, 3841-3844.

52 T. Wagner and U. Platt, Nature, 1998, 395, 486-490; T. Wagner, C. Leue, M. Wenig, K. Pfeilsticker and U. Platt, J. Geophys. Res., 2001, 106, 24,225-24, 235.

53 U. Frie $\beta$, J. Hollwedel, G. König-Langlo, T. Wagner and U. Platt, J. Geophys. Res., 2004, 109, D06305.

54 A. M. Rankin, E. W. Wolff and S. Martin, J. Geophys. Res., 2002, 107, 4683.

55 R. Fitzenberger, H. Bosch, C. Camy-Peyret, M. P. Chipperfield, H. Harder, U. Platt, B. M. Sinnhuber, T. Wagner and K. Pfeilsticker, Geophys. Res. Lett., 2000, 27, 2921-2924.

56 L. J. Carpenter, K. Hebestreit, U. Platt and P. S. Liss, Atmos. Chem. Phys., 2001, 1, 9-18.

57 A. Saiz-Lopez and J. M. C. Plane, Geophys. Res. Lett., 2004, 31, L04112.

58 G. McFiggans, J. M. C. Plane, B. J. Allan, L. J. Carpenter, H. Coe and C. O'Dowd, J. Geophys. Res., 2000, 105, 14,731-14,385.

59 O. W. Wingenter, M. K. Kubo, N. J. Blake, T. W. Smith, D. R. Blake and F. S. Rowland, J. Geophys. Res., 1996, 101, 4331-4340.

60 J. Stutz, R. Ackermann, J. D. Fast and L. Barrie, Geophys. Res. Lett., 2002, 29, 1380.

61 J. Y. Lu, W. H. Shroeder, L. A. Barrie, A. Steffen, H. E. Welch, K. Martin, W. L. Lockart, R. V. Hunt, G. Boila and A. Richter, Geophys. Res. Lett., 2001, 28, 3219-3222.

62 D. J. Creasey, G. E. Evans, D. E. Heard and J. D. Lee, J. Geophys. Res., 2003, 108, 4475. 
63 P. D. Lightfoot, R. A. Cox, J. N. Crowley, M. Destriau, G. D. Hayman, M. E. Jenkin, G. K. Moortgat and F. Zabel, Atmos. Environ., 1992, 10, 1805-1961.

64 U. Frieß, Spectroscopic measurements of atmospheric trace gases at Neumayer station, Antarctica, Ph.D. thesis, University of Heidelberg, Germany, 2001.
65 M. Van Roozendael, C. Fayt, J.-C. Lambert, I. Pundt, T. Wagner, A. Richter and K. Chance, Development of a bromine oxide product from GOME, Proc. ESAMS'99-European Symposium on Atmospheric Measurements from Space, ESTEC, Noordwijk, The Netherlands, 18-22 January 1999, WPP-161, p. 543-547, 1999. 